\title{
Macro and trace mineral constituents and radionuclides in mushrooms: health benefits and risks
}

\author{
Jerzy Falandysz • Jan Borovička
}

Received: 30 August 2012 /Revised: 23 October 2012 /Accepted: 24 October 2012 / Published online: 25 November 2012

(C) The Author(s) 2012. This article is published with open access at Springerlink.com

\begin{abstract}
This article reviews and updates data on macro and trace elements and radionuclides in edible wild-grown and cultivated mushrooms. A huge biodiversity of mushrooms and spread of certain species over different continents makes the study on their multi-element constituents highly challenging. A few edible mushrooms are widely cultivated and efforts are on to employ them (largely Agaricus spp., Pleurotus spp., and Lentinula edodes) in the production of selenium-enriched food (mushrooms) or nutraceuticals (by using mycelia) and less on species used by traditional medicine, e.g., Ganoderma lucidum. There are also attempts to enrich mushrooms with other elements than Se and a good example is enrichment with lithium. Since minerals of nutritional value are common constituents of mushrooms collected from natural habitats, the problem is however their co-occurrence with some hazardous elements including $\mathrm{Cd}, \mathrm{Pb}, \mathrm{Hg}, \mathrm{Ag}$, As, and radionuclides. Discussed is also the problem of erroneous data on mineral compounds determined in mushrooms.
\end{abstract}

Electronic supplementary material The online version of this article (doi:10.1007/s00253-012-4552-8) contains supplementary material, which is available to authorized users.

\footnotetext{
J. Falandysz $(\bowtie)$

Institute of Environmental Sciences \& Public Health,

University of Gdańsk,

Gdańsk, Poland

e-mail: jfalandy@chem.univ.gda.pl

J. Borovička

Nuclear Physics Institute, v.v.i.,

Academy of Sciences of the Czech Republic,

Řež 130 ,

CZ-250 68, Řež near Prague, Czech Republic

\section{J. Borovička}

Institute of Geology, v.v.i.,

Academy of Sciences of the Czech Republic,

Rozvojová 269,

CZ-165 00, Prague 6, Czech Republic
}

Keywords Environment $\cdot$ Food $\cdot$ Fungi $\cdot$ Organic food $\cdot$ Se bioenrichment $\cdot$ Wild food

\section{Introduction}

Mushrooms are heterotrophic eukaryotic organisms classified in the kingdom of Fungi. Recent estimates based on high-throughput sequencing methods suggest that there are as many as 5.1 million fungal species worldwide (Blackwell 2011). The European continent has witnessed the highest number of studies in this area, and in this continent, at least 75,000 species exist, and of these, more than 15,000 species are macrofungi, i.e., fungi forming fruit bodies (sporocarps) that are visible to the naked eye (Senn-Irlet et al. 2007). The fruit body is the morphological part of the fungus that bears spores and is commonly called mushroom. There are a variety of forms of mushrooms. Depending on the situation, context, and language, the term mushroom is used also as synonymous to any fungus. In the context of this article, the term mushroom relates to the fleshy fruit body of the macrofungi that can be edible or inedible regardless of its shape and kind. According to their lifestyle, mushrooms are recognized as saprotrophs, parasites, and mutualists - ectomycorrhizal symbionts (Gadd 2008).

The study of the role that fungi have played and are playing in geological processes is termed geomycology (Gadd 2007). The fundamental importance of fungi involves organic and inorganic transformations and element cycling, rock and mineral transformations, bioweathering, fungalclay interactions, metal-fungal interactions, and mycogenic mineral formation. However, despite the crucial roles of fungi in biogeochemical cycling of elements, the extent to which fungi play a critical role in the Earth's processes is not always appreciated (Hawksworth 2009).

Similar to plants and microbes, fungi are intimately involved in soil mineral weathering and element cycling in the 
critical zone (Amundson et al. 2007); their mycelia colonize both organic and mineral soils and produce a variety of active chemical compounds including enzymes (Baldrian 2008) and various organic acids (Stijve and de Meijer 1999; Wallander and Wickman 1999; van Schöll et al. 2006a).

Production of enzymes in saprotrophic macrofungi plays an important role in the transformation of humic substances including humus formation and mineralization (Baldrian 2008) and mobilization of metals associated with organic matter. Extracellular enzymes (1) allow access to organic matter in the microporous layer of soil; (2) transform soil organic matter, which is often insoluble or adsorbed on mineral surfaces, into soluble products; and (3) decrease the structural complexity of soil organic matter (Quiquampoix and Burns 2008). Through enzyme production, the ectomycorrhizal mushrooms can utilize organic $\mathrm{N}$ and $\mathrm{P}$ forms which would otherwise remain largely unavailable to roots (Landeweert et al. 2001). Nutrient mobilization from amino acids, peptides, proteins, amino sugars, chitin, and nucleic acids has been shown (Chalot and Brun 1998), together with transfer of $\mathrm{N}$ and $\mathrm{P}$ into the host plant (Antibus et al. 1997). Production of organic acids leads to chemical leaching of mineral surfaces and consequent mobilization of nutrients like $\mathrm{P}, \mathrm{K}, \mathrm{Ca}$, and $\mathrm{Mg}$ that can be translocated to the host plants (Jentschke et al. 2000; Wallander 2000a, b; Wallander and Wickman 1999).

Analogous to their organic nutrient mobilizing capabilities, the abilities of different ectomycorrhizal fungi to mobilize inorganic nutrients might be species specific (van Schöll et al. 2006b; Plassard et al. 2011). In vitro experiments have demonstrated that mycelia of mushrooms can solubilize various types of metals and minerals (Fomina et al. 2006, 2007). On the other hand, this process was often accompanied by precipitation of various "mycogenic" minerals on fungal hyphae (Gadd et al. 2012; Rhee et al. 2012). The interactions between ectomycorrhizal fungi and metal elements have been recently reviewed by Urban (2011). The complex chemical action of macrofungi in soils described above leads, however, to a very interesting and not yet wellunderstood phenomenon: uptake, transport, and accumulation of various chemical elements in mushroom fruit bodies (Fig. 1).

Apart from hyphae (mycelium), rhizomorphs, which are root-like structures and which are known to be spread by species over a huge area of forest, also take part in the uptake of mineral elements. The contribution of rhizomorphs as a highly efficient medium for water and mineral compounds uptake from soils seems to explain the presence of $\mathrm{Hg}$ and $\mathrm{Ag}$ in fruiting bodies of Armillaria solidipes (Falandysz et al. 2012e; J.F., unpublished). An individual organism of Armillaria bulbosa could spread the mycelium and rhizomorphs over $150,000 \mathrm{~m}^{2}$ of forest (Smith et al. 1992).

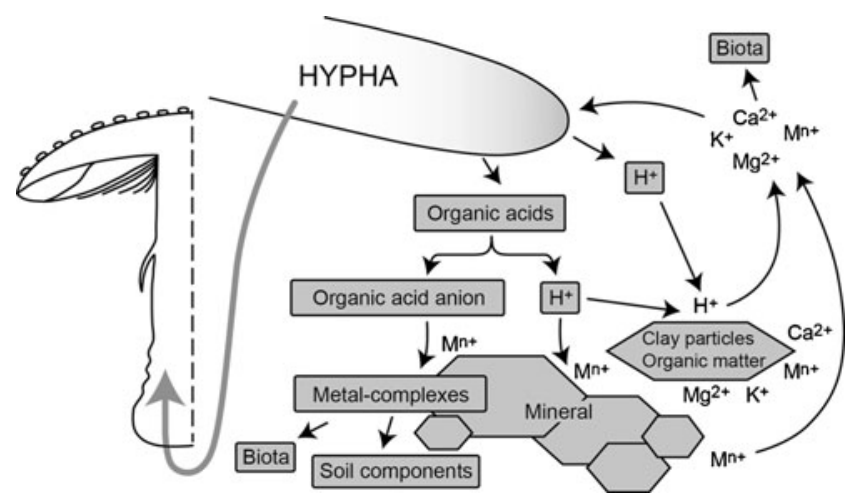

Fig. 1 Proton- and organic acid ligand-mediated dissolution of metals of soil components/minerals and their transfer to fruit body (modified from Gadd 2004)

\section{Historical and subject overview}

The first reports on the chemical composition of macrofungal fruit bodies appeared more than 100 years ago (Zellner 1907) and covered several macroelements including Fe and Mn. Curious enough, Friese (1929) had reported strikingly high Fe concentrations in Suillus variegatus that were rediscovered 46 years later (Drbal et al. 1975a). However, reliable data appeared with the development of advanced instruments and validated analytical methods, especially after 1970 (Drbal et al. 1975a, b; Stijve and Besson 1976; Byrne et al. 1976; Bakken and Olsen 1990; Falandysz et al. 2001). Very high concentrations of toxic metallic elements ( $\mathrm{Hg}, \mathrm{Cd})$, toxic metalloids (As), essential and toxic nonmetal (Se), and other elements ( $\mathrm{Ag}, \mathrm{Au}, \mathrm{Cs}, \mathrm{Rb}, \mathrm{V}, \mathrm{Zn}$ ) found in mushrooms from "background areas" have led to many studies which are, however, mostly from European countries. These studies were focused especially on:

1. Toxic metallic elements and metalloids (As, $\mathrm{Sb}$ ) which might represent a risk for mushroom consumers (see below)

2. Possibilities of using mushrooms for environmental monitoring (Wondratschek and Röder 1993)

3. Radioactive contamination before and after the Chernobyl accident (Reisinger 1994; see below)

4. Chemical form of accumulated elements in mushroom fruit bodies (Collin-Hansen et al. 2003; Šlejkovec et al. 1997, 2000)

5. Influence of environmental pollution on metallic elements accumulation (Kalač et al. 1991; Borovička et al. 2006, 2010b; Falandysz et al. 2012b; Kojta et al. 2012)

6. Chemotaxonomical and mycological systematics significance of trace element accumulation (Stijve et al. 1998, 2001; Petrini et al. 2009)

7. Mushroom cultivation on artificially metallic elementenriched substrates and media (Falandysz et al. 1994b; Crane et al. 2010) 
8. Use of stable and radioactive isotopes for applications in the study of fungi (Rühm et al. 1997; Komárek et al. 2007; Guillén et al. 2009; Hobbie and Agerer 2010; Agerer et al. 2012).

The most recent studies usually considered various ecological/environmental aspects (Collin-Hansen et al. 2005; Falandysz et al. 2008a, 2012a; Borovička et al. 2010a; Vinichuk et al. 2011; Aloupi et al. 2011; Gryndler et al. 2012) or molecular approaches are applied to investigate metal transport and sequestration in macrofungi (Courbot et al. 2004; Ramesh et al. 2009; Blaudez and Chalot 2011; Osobová et al. 2011).

\section{Bioaccumulation in macrofungi}

In contrast to vascular plants in which high concentrations of metals are mostly observed above metal-rich soils (Kabata-Pendias 2011), macrofungi can accumulate extremely high concentrations of metallic elements even when growing above soils with low metal contents. Furthermore, macrofungi reveal variable and highly specific ability to take up various trace elements (metallic elements, metalloids, and halogens) from soils and accumulate them in their fruit bodies. The ratio of an element in fruit body to its concentration in soil or, more specifically, to its mobility in soil (i.e., extractability by appropriate chemicals), so-called bioaccumulation factor (BAF), describes the ability of a fungus to accumulate a particular element. Apart from BAF, some other synonymous unit-less terms (transfer rate; transfer factor; transfer coefficient; translocation factor; concentration ratio; enrichment factor; index of bioaccumulatiuon, bioconcentration factor), which are simply a quotient from element concentration distributed between two phases, are also used by authors to estimate the potential of species to accumulate elements from soils or other substratum.

Elements typically accumulated in (at least some) macrofungi (BAF $>1$ ) include $\mathrm{Au}, \mathrm{Ag}, \mathrm{As}, \mathrm{Br}, \mathrm{Cd}, \mathrm{Cl}, \mathrm{Cs}, \mathrm{Cu}, \mathrm{Hg}$, $\mathrm{Rb}$, Se, V, and Zn. Elements with typically low concentrations in macrofungi $(\mathrm{BAF}<1)$ include $\mathrm{Co}, \mathrm{Cr}, \mathrm{F}, \mathrm{I}, \mathrm{Ni}, \mathrm{Sb}$, $\mathrm{Sn}, \mathrm{Th}, \mathrm{U}$, and rare earth elements.

In some cases, concentrations of metallic element or metalloid might be rather high in some macrofungi (e.g., 10 or more times greater than in common ones, but $\mathrm{BAF}<$ $1)$; this phenomenon has been reported for Fe in $S$. variegatus and Hygrophoropsis aurantiaca, Co in Agaricus spp., $\mathrm{Mn}$ in Phallaceae and Panaeolus spp., $\mathrm{Pb}$ in Lycoperdon, and $\mathrm{Sb}$ in Suillus spp. and Chalciporus piperatus (Falandysz et al. 2001b; Borovička et al. 2006).

Factors influencing the bioaccumulation of trace elements in macrofungi and the biological importance of the accumulation process itself are poorly understood. However, the following fundamentals have been recognized:

1. Natural factors (bedrock geochemistry): The type of geological bedrock influences the concentrations of trace elements. Furthermore, $\mathrm{pH} / \mathrm{Eh}$ conditions, organic matter content, and other factors influence the "mobility" of elements and their availability to biota (Kabata-Pendias 2011). The influence of these factors on trace element uptake in macrofungi has been poorly investigated. Gast et al. (1988) did not find any influence of soil $\mathrm{pH}$ or organic matter on $\mathrm{Cd}, \mathrm{Cu}, \mathrm{Pb}$, and $\mathrm{Zn}$ in Amanita muscaria, Amanita rubescens, Hygrophoropsis aurantiaca, Lepista nabularis, Paxillus involutus, and Suillus luteus that emerged in natural habitats. In other studies, they did not influence the accumulation of $\mathrm{Ag}, \mathrm{Al}, \mathrm{Ba}, \mathrm{Ca}, \mathrm{Cd}, \mathrm{Co}$, $\mathrm{Cr}, \mathrm{Cu}, \mathrm{Fe}, \mathrm{Hg}, \mathrm{K}, \mathrm{Mg}, \mathrm{Mn}, \mathrm{Na}, \mathrm{Ni}, \mathrm{Sr}, \mathrm{Pb}, \mathrm{Rb}$, and $\mathrm{Zn}$ by A. muscaria, P. involutus, and Leccinum scabrum (Brzostowski et al. 2009, 2011a; Falandysz and Bielawski 2007; Falandysz and Brzostowski 2007; J.F., unpublished).

Concentrations of $\mathrm{Ni}$ and $\mathrm{Cr}$ were elevated in macrofungi from serpentine soils (Aloupi et al. 2011). Interestingly, metal concentrations in fruit bodies of ectomycorrhizal fungi growing on the same site can/could be very similar over the years (Brzostowski et al. 2011b; J.B., unpublished). The influence of environmental factors was studied also by Campos et al. (2009) who, however, used an inappropriate analytical method, and the published results are not reliable_-see Borovička et al. (2011). As demonstrated in a study by Cen et al. (2012), the addition of chelating agents such as ethylenediaminetetraacetic acid and nitrilotriacetate to soil in a pot study enhanced the bioaccumulation of $\mathrm{Cd}, \mathrm{Cu}$, and $\mathrm{Pb}$ in Coprinus comatus, while the addition of citric acid did not.

2. Metalliferous areas and environmental pollution: Naturally or artificially elevated levels of metals in soils usually result in greater concentrations in fruit bodies. This has been demonstrated for many elements including $\mathrm{Au}$ (Borovička et al. 2010a), Ag (Borovička et al. 2005, 2010b; Kojta et al. 2012), As (Larsen et al. 1998), Cd (Kalač et al. 1991; Falandysz et al. 2011), Cu (Svoboda et al. 2000), Hg (Bargagli and Baldi 1984; Falandysz et al. 2012c, 2012e), Ni (Barcan et al. 1998), Pb (Kalač et al. 1991), and Sb (Borovička et al. 2006).

3. Fungal lifestyle: Concentrations of $\mathrm{Hg}, \mathrm{Cd}, \mathrm{Pb}$ and $\mathrm{Pb}$ are usually greater in terrestrial saprotrophs than those in ectomycorrhizal fungi (Borovička and Řanda 2007 and many others). On the other hand, concentrations of alkali metals, $\mathrm{Rb}$ and $\mathrm{Cs}$, are generally greater in ectomycorrhizal species (Klán et al. 1988; Řanda and Kučera 2004; see also Table 12). Some of these differences might be explained by contrasting nutrition 
strategy of both groups and consequently the differences in the distribution of mycelia in soil profiles (Luis et al. 2005; Christ et al. 2011).

4. Bioaccumulation of metallic elements, metalloids and non-metals $(\mathrm{Se})$ in fruit bodies is highly species specific: Some macrofungi are able to accumulate elements much more effectively than others; the ability to accumulate a particular element is a characteristic feature of a particular fungal species. In various macrofungi growing above the same substrate, concentrations of elements can vary over a wide range and can differ even a thousand times from species to species (see, e.g., Lavola et al. 2011).

5. The accumulation process can be highly element specific: Macrofungi may even discriminate elements with similar properties and chemical behavior (homologues). A typical example might be hyperaccumulation/discrimination of $\mathrm{As} / \mathrm{Sb}$ in Sarcosphaera coronaria (see below).

\section{Hyperaccumulation}

An extraordinarily high ability of a plant or macrofungal species to accumulate a trace element in its tissues is called hyperaccumulation. To be defined as a hyperaccumulator, the metal concentration should be at least about 100 times greater than the values to be expected in nonaccumulating species on the same substrate (for discussion on this term, see Borovička et al. 2007).

A. muscaria was the first recognized fungal hyperaccumulator. This temperate zone species hyperaccumulates vanadium, and this also applies to its relatives such as Amanita regalis and Amanita velatipes. Whereas concentrations of $\mathrm{V}$ in other mushrooms hardly exceed $1 \mathrm{mg} \mathrm{kg}^{-1}$ (related to dry matter, dm), these Amanita spp. accumulate even hundreds of milligram per kilogram of $\mathrm{dm}$. In fruit body biomass, $\mathrm{V}$ is present as amavadin, an eight-coordinate $\mathrm{V}$ complex of unclear biological function (Garner et al. 2000).

$S$. coronaria, an ectomycorrhizal ascomycete growing on calcareous bedrock in temperate climate regions, hyperaccumulates arsenic. Despite being relatively low naturally in soils, the As concentrations are commonly as high as $1,000 \mathrm{mgkg}^{-1}$ $\mathrm{dm}$ in fruit bodies of this species (Stijve et al. 1990), with the greatest ever reported value being $7,090 \mathrm{mgkg}^{-1} \mathrm{dm}$ (Borovička 2004). The main As compound identified in biomass was methylarsonic acid (Byrne et al. 1995). Although less toxic than arsenic trioxide, it is still relatively dangerous. Therefore, the Pink Crown should not be eaten though it used to be considered edible in Europe. Hyperaccumulation of As occurs also in several Basidiomycetes (J.B., unpublished; and see also text below).

The most recently discovered hyperaccumulators are Amanita species of the section Lepidella (Borovička et al.
2007). The European Amanita strobiliformis like some others growing worldwide hyperaccumulates silver. Despite very low natural levels in soils (below $1 \mathrm{mgkg}^{-1} \mathrm{dm}$ ), $\mathrm{Ag}$ concentrations in Amanita spp. may be more than 2,000 times greater and commonly amount to hundreds of milligram per kilogram of dry matter; the greatest reported value was $1,253 \mathrm{mgkg}^{-1}$ $\mathrm{dm}$. Investigation on the chemical form of $\mathrm{Ag}$ has revealed that $A$. strobiliformis employs cysteine-rich, low molecular weight proteins (metallothioneins) to sequester intracellular $\mathrm{Ag}$ in its fruit bodies and extraradical mycelium (Osobová et al. 2011).

The biological importance of elemental hyperaccumulation in macrofungi is unclear but this extraordinary feature can be thought of in theory as being attributable to the "defense hypothesis" (Boyd 2007). It has been shown in vascular plants that elemental hyperaccumulation may have several functions, including plant defense against natural enemies; at least some tests have demonstrated defense by hyperaccumulated As, Cd, $\mathrm{Ni}, \mathrm{Se}$, and $\mathrm{Zn}$ in plants. In view of this fact, the high $\mathrm{Ag}$ concentrations in hyperaccumulating macrofungal species might have some protective effect against pathogenic microfungi, bacteria, insect larvae, or gastropoda, but this is yet to be tested. Interestingly, Gryndler et al. (2012) have demonstrated that Ag-rich fungal biomass strongly influences the soil bacterial community.

\section{Edible mushrooms and mineral constituents}

Numerous wild-grown mushrooms are more or less valued as gourmet by nations worldwide (Tüzen et al. 2007; Zhang et al. 2010; Costa-Silva et al. 2011; Li et al. 2011; Nnorom et al. 2012a; Giannaccini et al. 2012; Figs. S1-S4, Supporting material). Also, in China and elsewhere, mushrooms collected in the wild are still used in traditional medicine, e.g., Ganoderma lucidum (Zhao et al. 2004), which is also cultivated in China. Another example can be sclerotium (or storage tuber that is formed by dense mass of mycelium) of Wolfiporia extensa used in Chinese traditional medicine and of Pleurotus tuber-regium that are also considered a popular food (Figs. S5-S7, Supporting material). Products based on mycelium that were biotechnologically enriched in desired trace element could be considered possible nutraceuticals (food supplements), and an example can be Se-enriched mycelium of Lenitula edodes mushroom (Turło et al. 2010). There are growing attempts to enrich cultivated mushrooms with biologically active and medicine minerals desired in human nutrition, and typical examples are Se and Li (Zhao et al. 2004; Silva et al. 2010; Bhatia et al. 2011; Hong et al. 2011; Assunção et al. 2012).

Mushrooms are valued due to their aroma and taste, as well as their proteins, vitamins, and low fat contents, and they are considered as products rich in mineral compounds. 
Apart from the abundance of minerals desired in human nutrition in mushrooms, undesired potentially toxic elements including $\mathrm{Cd}$ and $\mathrm{Hg}$ also occur sometimes at elevated concentrations (Falandysz et al. 2011; Gucia et al. 2012a, b; Giannaccini et al. 2012; Jarzyńska et al. 2012a).

First of all, most of the estimated 2,000 species of edible wild mushrooms grown worldwide are poorly characterized with respect to their multi-mineral composition. Apart from the variability introduced by natural conditions (type of soil bedrock, habitat, environmental factors), little is known of the influence of the processing, storage, and cooking on the contents and changes in mineral compounds composition of mushrooms as well as their accessibility and bio-availability from mushroom meals to man (Svoboda et al. 2002; Sun et al. 2012). Certain mushrooms can be processed and cooked in various ways. An example is Tricholoma equestre, which is suitable for drying, pickling, salting, stewing, souring, and freezing. In a recipe on mushroom soups, "the Yellow Knights' soup," it is noted that the fresh specimens of $T$. equestre do not need to be blanched before soup cookingthat is the specimens, when "cleaned up, cut and well rinsed in running tap water, are poured directly into boiling bullion and boiled for $40 \mathrm{~min}$ ". A common practice is blanching of mushrooms (a short-time boiling) by boiling them for 2-3, 5 , or $10 \mathrm{~min}$ and slightly salted water-depending on the cuisine recipes (Maćkiewicz and Falandysz 2012). Preservation of mushrooms by salting is a practice in China and is good for Boletus and other species (Figs. S8$\mathrm{S} 10$ in Supporting material). Those factors can influence the content (with the possibility of leaching) and chemical species of trace elements of mushroom meals. In China, Tricholoma matsutake can be eaten raw, and raw Agaricus bisporus can be found in salads worldwide. However, this is no longer a common practice in the modern world, and eating of any mushroom raw is not recommended by the authors. When well cooked, mushrooms by volume could be important and attractive components of meals (Fig. S1 in Supporting material).

Some of the mineral constituents, including metallic elements, are macro- and micronutrients to mushrooms. The essential elements are $\mathrm{K}, \mathrm{P}, \mathrm{Mg}, \mathrm{Ca}, \mathrm{Na}, \mathrm{Zn}, \mathrm{Cu}, \mathrm{Mn}, \mathrm{Ni}$, and $\mathrm{Co}$, while many others have no known biological function. Selenium can be found in all mushrooms but species vary in their Se contents and a few can be considered abundant in this antioxidant (Falandysz 2008). As mentioned, example of elements that are well bioaccumulated by numerous species are $\mathrm{Au}, \mathrm{Ag}, \mathrm{As}, \mathrm{Br}, \mathrm{Cd}, \mathrm{Cl}, \mathrm{Cs}, \mathrm{Cu}$, $\mathrm{Hg}, \mathrm{Rb}, \mathrm{Se}$, and $\mathrm{Zn}(\mathrm{BAF}>1)$. Lead, for which $\mathrm{BAF}$ is usually $<1$, is relatively abundant in forest topsoil in background areas and is also a common trace contaminant of mushrooms. Fungi have low potential to bioaccumulate $\mathrm{Pb}$ and this keeps its concentration it their flesh below actual limits of tolerable intake from foods (Chudzyński and
Falandysz 2008; García et al. 2009; Frankowska et al. 2010; Jarzyńska et al. 2011, 2012b; Giannaccini et al. 2012; Jarzyńska and Falandysz 2012a, b; Malinowska et al. 2004; Rudawska and Leski 2005a, b; Szubstarska et al. 2012).

\section{Macro and trace mineral constituents of nutritional value}

Wild-grown edible mushrooms can contain certain minerals essential to humans at relatively high concentrations, and for trace elements such as $\mathrm{Cu}$ and $\mathrm{Zn}$, published data are available for numerous but not all species. Some other essential elements depending on species are a little less or not covered at all in literature. However, this is changing in recent years as more and high quality data become available from scientific literature. Within this mini-review, focus is given mostly to elements that are of greater nutritional/medical and toxicological significance and largely by using popular wild-grown Boletus edulis and Macrolepiota procera and cultivated A. bisporus, Pleurotus ostreatus, and some other Pleurotus spp. and L. edodes for which some analytical data were published as examples.

Metals such as $\mathrm{K}, \mathrm{P}, \mathrm{Mg}, \mathrm{Ca}, \mathrm{Na}, \mathrm{Cu}$, and $\mathrm{Zn}$ are among the vital ions to body liquids and tissues and are co-factors of numerous enzymes, while their concentrations in the body of healthy biota are regulated. The flesh of mushrooms can be considered as rich in $\mathrm{K}$ and $\mathrm{P}$, and it can also be considered as abundant in trace elements such as $\mathrm{Cu}$ and $\mathrm{Zn}$. Both $\mathrm{Cu}$ and $\mathrm{Zn}$ in the flesh of mushrooms collected from background areas are of nutritional value for humans. The situation can be different if the mushrooms emerged at sites polluted with $\mathrm{Cu}$ or $\mathrm{Zn}$. This is because in polluted soils other toxic metals $(\mathrm{Cd}, \mathrm{Pb}, \mathrm{Hg})$ can co-occur with $\mathrm{Cu}$ and $\mathrm{Zn}$ and can be bioaccumulated to concentrations much above typical contents of edible species and could become noxious to mushrooms (Collin-Hansen et al. 2005).

Potassium plays many important roles as an essential metal in vegetation. This metal occurred in caps of $B$. edulis from many sites at $25 \pm 0$ to $29 \pm 3 \mathrm{~g} \mathrm{~kg}^{-1} \mathrm{dm}$ on average, and in stipes, at 20-40\% less (Table 1). The edible cap of $M$. procera is also rich in $\mathrm{K}$, and its typical concentration is $26 \pm$ 4 to $49 \pm 14 \mathrm{~g} \mathrm{~kg}^{-1} \mathrm{dm}$ (Table 1), but the stipes are sometimes richer in this element (Gucia et al. 2012a, b). Wild-grown $P$. tuber-regium showed $\mathrm{K}$ in sclerotia (storage tuber) at a concentration one order of magnitude less compared to the fruit bodies of cultivated Pleurotus spp. (Table 1). Mycelium compared to fruit bodies of wild-grown mushrooms is also one order of magnitude poorer in $\mathrm{K}$ (Vinichuk et al. 2011). The values of concentrations in Tables 1 and 12 imply that there are similarities in $\mathrm{K}$ contents of fruit bodies of macromycetes, while fluctuations seem be more due to 
Table 1 Potassium in mushrooms (adapted)

\begin{tabular}{lllll}
\hline Species & \multicolumn{2}{l}{ Content $\left(\mathrm{gkg}^{-1} \mathrm{dm}\right)$} & & Ref. \\
\cline { 2 - 4 } & Mean/s $\pm \mathrm{SD}$ & Median/s & Total range & \\
\hline B. edulis (caps) & $25 \pm 0-29 \pm 3$ & $20-38$ & $14-41$ & $\mathrm{~A}$ \\
M. procera (caps) & $26 \pm 4-49 \pm 14$ & $25-74$ & $17-110$ & $\mathrm{~B}$ \\
L. pseudoscabrum (caps) & $40 \pm 3$ & 41 & $34-43$ & $\mathrm{C}$ \\
L. duriusculum (caps) & $37 \pm 3$ & 37 & $33-44$ & $\mathrm{D}$ \\
L. scabrum (caps) & $34 \pm 3-52 \pm 4$ & $34-52$ & $26-59$ & $\mathrm{E}$ \\
L. rufum (caps) & $35 \pm 81-42 \pm 45$ & $31-41$ & $25-50$ & $\mathrm{~F}$ \\
A. bisporus (caps) & $40 \pm 0$ & - & - & $\mathrm{G}$ \\
A. bisporus (whole) & $38 \pm 1-40 \pm 1$ & - & - & $\mathrm{H}$ \\
A. bisporus (canned) & $0.45 \pm 0.01-1.3 \pm 0.1$ & - & - & $\mathrm{H}$ \\
A. subrufescens (caps) & $28 \pm 2-32 \pm 1$ & - & - & $\mathrm{I}$ \\
P. tuber-regium (sclerotia) & $3.4 \pm 1.6-4.1 \pm 2.4$ & 3.2 & $1.3-10$ & $\mathrm{~J}$ \\
Pleurotus spp. (whole) & $22 \pm 1-40 \pm 2$ & - & - & $\mathrm{K}$ \\
P. ostreatus (caps) & $31 \pm 6$ & - & - & $\mathrm{G}$ \\
L. edodes (whole) & $26 \pm 0$ & - & - & $\mathrm{K}$ \\
L. edodes (caps) & $23 \pm 4$ & - & - & $\mathrm{G}$ \\
\hline
\end{tabular}

the stage of maturity of the carpophore and the site rather than to the species of the fungus (Tables 1 and 12).

Phosphorus is abundant in wild-grown edible mushrooms and a concentration range of $10 \pm 1$ to $15 \pm 2 \mathrm{~g} \mathrm{~kg}^{-1}$ $\mathrm{dm}$ was reported in the caps of $M$. procera, while the concentrations (Table 2) in stipes were $40-50 \%$ less (Gucia et al. 2012a, b). The mushroom M. procera is more abundant in $\mathrm{P}$ than certain other wild-grown species for which data are available. For example, Leccinum duriusculum (rare species) and L. scabrum showed P in caps of 5.7 and $5.7 \mathrm{~g} \mathrm{~kg}^{-1} \mathrm{dm}$ (median values), and in stipes, these were 1.5 and $2.2 \mathrm{~g} \mathrm{~kg}^{-1} \mathrm{dm}$, respectively (Jarzyńska and Falandysz 2012b; Zhang et al. 2012). For Suillus grevillei and Xerocomus badius, the concentrations of $\mathrm{P}$ are largely similar to those of Leccinum spp. (Table 2), while the values for $S$. grevillei and $X$. badius in stipes were much less (Chudzyński and Falandysz 2008; Kojta et al. 2012). The concentrations reported for Cantharellus cibarius (whole fruit bodies) did not deviate from those reported for the species mentioned (Table 2). Also for some cultivated Agaricus spp., Pleurotus spp., and L. edodes, the content of $\mathrm{P}$ was similar to that of wild-grown species but much less in commercially processed (conserved) A. bisporus and also in the sclerotia of P. tuber-regium (Table 2).

Sodium in the form of $\mathrm{NaCl}$ is added to many food products and meals, and the problem usually is its excessive
Table 2 Phosphorus in mushrooms (adapted)

A (Jarzyńska et al. 2011; Kojta et al. 2011; Gucia et al. 2012a, b); B (Jarzyńska and Falandysz 2012b); C (Zhang et al. 2013); D (Chudzyński and Falandysz 2008; Falandysz et al. 2012a); E (Kojta et al. 2012); F (Falandysz et al. 2012b); G (Vetter et al. 2005); H (Vetter 2003); I (Györfi et al. 2010); J (Nnorom et al. 2012b)

\begin{tabular}{lllll}
\hline Species & \multicolumn{2}{l}{ Content $\left(\mathrm{gkg}^{-1} \mathrm{dm}\right)$} & & Ref. \\
\cline { 2 - 5 } & Mean/s $\pm \mathrm{SD}$ & Median/s & Total range & \\
\hline M. procera (caps) & $10 \pm 1-15 \pm 2$ & $10-19$ & $7.8-24$ & $\mathrm{~A}$ \\
L. duriusculum (caps) & $5.8 \pm 0.8$ & 5.7 & $4.7-7.6$ & $\mathrm{~B}$ \\
L. scabrum (caps) & $6.1 \pm 1.1$ & 5.7 & $4.6-8.9$ & $\mathrm{C}$ \\
S. grevillei (caps) & $6.4 \pm 1.3-11 \pm 2$ & $6.6-11$ & $2.6-13$ & $\mathrm{D}$ \\
X. badius (caps) & $3.9 \pm 1.4-6.4 \pm 1.1$ & $3.6-6.0$ & $2.1-8.5$ & $\mathrm{E}$ \\
C. cibarius (whole) & $3.0 \pm 0.2-4.8 \pm 0.7$ & $3.0-4.8$ & $2.6-6.0$ & $\mathrm{~F}$ \\
A. bisporus (caps) & $12 \pm 2$ & - & - & $\mathrm{G}$ \\
A. bisporus (whole) & $10 \pm 0-10 \pm 0$ & - & - & $\mathrm{H}$ \\
A. bisporus (conserved) & $3.8 \pm 0.1-4.5 \pm 0.1$ & - & - & $\mathrm{H}$ \\
A. subrufescens (caps) & $10 \pm 1-13 \pm 0$ & - & - & $\mathrm{I}$ \\
P. ostreatus (caps) & $7.0 \pm 3.0$ & - & - & $\mathrm{G}$ \\
P. tuber-regium (sclerotia) & $1.9 \pm 0.9-2.5 \pm 1.1$ & 2.2 & $0.56-3.9$ & $\mathrm{I}$ \\
L. edodes (caps) & $7.4 \pm 1.6$ & - & - & $\mathrm{G}$ \\
\hline
\end{tabular}


Table 3 Sodium in mushrooms (adapted)

\begin{tabular}{lllll}
\hline Species & \multicolumn{2}{l}{ Content $\left(\mathrm{mgkg}^{-1} \mathrm{dm}\right)$} & & \multirow{2}{*}{ Ref. } \\
\cline { 2 - 5 } & Mean/s $\pm \mathrm{SD}$ & Median/s & Total range & \\
\hline B. edulis (caps) & $150 \pm 140-360 \pm 70$ & $100-380$ & $17-550$ & $\mathrm{~A}$ \\
M. procera (caps) & $44 \pm 14-410 \pm 300$ & $20-500$ & $15-830$ & $\mathrm{~B}$ \\
L. pseudoscabrum (caps) & $520 \pm 240$ & 560 & $170-860$ & $\mathrm{C}$ \\
L. duriusculum (caps) & $340 \pm 130$ & 310 & $190-660$ & $\mathrm{D}$ \\
L. scabrum (caps) & $270 \pm 87-530 \pm 240$ & $270-480$ & $120-1,300$ & $\mathrm{E}$ \\
L. rufum (caps) & $60 \pm 41-620 \pm 260$ & $30-550$ & $23-1,200$ & $\mathrm{~F}$ \\
A. bisporus (caps) & $700 \pm 120$ & - & - & $\mathrm{G}$ \\
A. bisporus (whole) & $860 \pm 23-850 \pm 25$ & - & - & $\mathrm{H}$ \\
A. bisporus (conserved) & $16,000 \pm 1,200-25,000 \pm 0$ & - & - & $\mathrm{H}$ \\
A. subrufescens (caps) & $110 \pm 5-220 \pm 40$ & - & - & $\mathrm{J}$ \\
Pleurotus spp. (whole) & $220 \pm 60-1,400 \pm 460$ & - & - & $\mathrm{G}$ \\
P. ostreatus (caps) & $270 \pm 41$ & - & - & $\mathrm{G}$ \\
L. edodes (whole) & $1,000 \pm 10$ & - & - & $\mathrm{J}$ \\
L. edodes (caps) & $440 \pm 91$ & - & - & $\mathrm{G}$ \\
\hline
\end{tabular}

intake but it is usually not in deficit in the human body. Mushrooms as organic food can be considered low in this element. For example, in the caps of $B$. edulis, the median sodium concentrations of 100 to $380 \mathrm{mg} \mathrm{kg}^{-1} \mathrm{dm}$ and in $M$. procera at 40 to $500 \mathrm{mg} \mathrm{kg}^{-1} \mathrm{dm}$ have been reported (Table 3). Stipes of $B$. edulis and $M$. procera are about twice more abundant in $\mathrm{Na}$ than the caps (Falandysz et al. 2011; Gucia et al. 2012a, b). The values of $\mathrm{Na}$ for B. edulis and $M$. procera seem to agree with the concentrations reported in some cultivated mushrooms, i.e., three Pleurotus spp. and $L$. edodes and of some other species but preserved (in brine in tin) A. bisporus is rich of hidden $\mathrm{Na}$ (Tables 3 and 12).
Magnesium occurs in a very similar concentration in many mushrooms both wild grown and cultivated (Table 4). Caps of B. edulis contained $\mathrm{Mg}$ at 680 to $930 \mathrm{mg} \mathrm{kg}^{-1} \mathrm{dm}$ and less than half this concentration were in stipes (Falandysz et al. 2011). Magnesium contents of processed $A$. bisporus is about half the contents of unprocessed mushrooms, and it seems that large amounts of elements can be lost from this species when boiled in saline water (Table 4).

Calcium in caps of B. edulis, M. procera, and Leccinum spp. are in similar concentrations and more $\mathrm{Ca}$ have been reported in cultivated mushrooms (Table 5). An exception
Table 4 Magnesium in mushrooms (adapted)
A (Falandysz et al. 2008a, 2011; Frankowska et al. 2010; Zhang et al. 2010); B (Jarzyńska et al. 2011; Kojta et al. 2011; Gucia et al. 2012a, b); C (Jarzyńska and Falandysz 2012a); D (Jarzyńska and Falandysz 2012b); E (Falandysz et al. 2007e; Zhang et al. 2013); F (J.F., unpublished); G (Vetter et al. 2005); $\mathrm{H}$ (Vetter 2003); I (Györfi et al. 2010); J (Manzi et al. 1999)

\begin{tabular}{lllll}
\hline Species & \multicolumn{2}{l}{ Content $\left(\mathrm{mgkg}^{-1} \mathrm{dm}\right)$} & & \multirow{2}{*}{ Ref. } \\
\cline { 2 - 5 } & Mean/s $\pm \mathrm{SD}$ & Median/s & Total range & \\
\hline B. edulis (caps) & $590 \pm 80-960 \pm 94$ & $680-930$ & $330-1,200$ & $\mathrm{~A}$ \\
M. procera (caps) & $860 \pm 900-2,000 \pm 200$ & $840-2,000$ & $750-2,400$ & $\mathrm{~B}$ \\
L. pseudoscabrum (caps) & $1,200 \pm 56$ & 1,200 & $1,000-1,200$ & $\mathrm{C}$ \\
L. duriusculum (caps) & $1,100 \pm 82$ & 1,100 & $920-1,200$ & $\mathrm{D}$ \\
L. scabrum (caps) & $990 \pm 740-1,200 \pm 100$ & $1,000-1,200$ & $650-1,300$ & $\mathrm{E}$ \\
L. rufum (caps) & $900 \pm 600-1,300 \pm 1,300$ & $820-1,200$ & $600-1,500$ & $\mathrm{~F}$ \\
A. bisporus (caps) & $1,400 \pm 990$ & - & - & $\mathrm{G}$ \\
A. bisporus (whole) & $1,100 \pm 25-1,100 \pm 38$ & - & - & $\mathrm{H}$ \\
A. bisporus (conserved) & $390 \pm 20-470 \pm 22$ & - & - & $\mathrm{H}$ \\
A. subrufescens (caps) & $1,000 \pm 95-1,300 \pm 23$ & - & - & $\mathrm{I}$ \\
Pleurotus spp. (whole) & $1,300 \pm 70-2,000 \pm 14$ & - & - & $\mathrm{J}$ \\
P. ostreatus (caps) & $1,400 \pm 320$ & - & - & $\mathrm{G}$ \\
L. edodes (whole) & $1,200 \pm 52$ & - & - & $\mathrm{J}$ \\
L. edodes (caps) & $1,300 \pm 180$ & - & $\mathrm{G}$ \\
\hline
\end{tabular}


Table 5 Calcium in mushrooms (adapted)
A (Falandysz et al. 2008a, 2011; Frankowska et al. 2010; Zhang et al. 2010); B (Jarzyńska et al. 2011; Kojta et al. 2011; Gucia et al. 2012a, b); C (Jarzyńska and Falandysz 2012a); D (Jarzyńska and Falandysz 2012b); E (Falandysz et al. 2007e; Zhang et al. 2013); F (J.F., unpublished); $\mathrm{G}$ (Vetter 2003); $\mathrm{H}$ (Györfi et al. 2010); I (Manzi et al. 1999)

\begin{tabular}{lllll}
\hline \multirow{2}{*}{ Species } & \multicolumn{2}{l}{ Content $\left(\mathrm{mgkg}^{-1} \mathrm{dm}\right)$} & & \multirow{2}{*}{ Ref. } \\
\cline { 2 - 5 } & Mean/s $\pm \mathrm{SD}$ & Median/s & Total range & \\
\hline B. edulis (caps) & $38 \pm 25-190 \pm 110$ & $29-170$ & $5.6-420$ & $\mathrm{~A}$ \\
M. procera (caps) & $68 \pm 81-320 \pm 280$ & $54-290$ & $18-970$ & $\mathrm{~B}$ \\
L. pseudoscabrum (caps) & $110 \pm 36$ & 110 & $67-220$ & $\mathrm{C}$ \\
L. duriusculum (caps) & $88 \pm 26$ & 87 & $59-150$ & $\mathrm{D}$ \\
L. scabrum (caps) & $54 \pm 20-140 \pm 49$ & $52-150$ & $27-200$ & $\mathrm{E}$ \\
L. rufum (caps) & $60 \pm 30-170 \pm 50$ & $50-170$ & $20-400$ & $\mathrm{~F}$ \\
A. bisporus (caps) & $1,400 \pm 530$ & - & - & $\mathrm{G}$ \\
A. bisporus (whole) & $860 \pm 72-890 \pm 0$ & - & - & $\mathrm{G}$ \\
A. bisporus (conserved) & $2,100 \pm 140-2,600 \pm 33$ & - & - & $\mathrm{G}$ \\
A. subrufescens (caps) & $570 \pm 39-1,100 \pm 57$ & - & - & $\mathrm{H}$ \\
Pleurotus spp. (whole) & $190 \pm 21-490 \pm 15$ & - & - & $\mathrm{I}$ \\
P. ostreatus (caps) & $820 \pm 110$ & - & - & $\mathrm{G}$ \\
L. edodes (whole) & $420 \pm 20$ & - & - & $\mathrm{I}$ \\
L. edodes (caps) & $1,100 \pm 130$ & - & - & $\mathrm{G}$ \\
\hline
\end{tabular}

can be preserved (in brine in tin) A. bisporus that contained $\mathrm{Ca}$ at concentrations $>2,000 \mathrm{mg} \mathrm{kg}^{-1} \mathrm{dm}$, but this could be due to $\mathrm{Ca}$ from industrial brine (Table 5). In B. edulis, $M$. procera, and Leccinum spp., both caps and stipes are similarly rich in Ca (Falandysz et al. 2011; Gucia et al. 2012a, b; Jarzyńska and Falandysz 2012a, b; Zhang et al. 2012).

Copper in caps of $B$. edulis from many sites was at 24 to $79 \mathrm{mg} \mathrm{kg}^{-1} \mathrm{dm}$ (median) (Table 6), and the stipes contained less than half of these amounts (Falandysz et al. 2011). Some quality data on $\mathrm{Cu}$ for $B$. edulis are also available from other sources (Collin-Hansen et al. 2002; Řanda and Kučera 2004). The species Boletus tomentipes collected in
Yunnan (China) seems to be less rich in $\mathrm{Cu}$ compared to $B$. edulis (Table 6). Some mushrooms of the genus Leccinum, which are related to the genus Boletus, showed $\mathrm{Cu}$ in a similar concentration, and Leccinum rufum with $\mathrm{Cu}$ contents of 45 to 97 (median) $\mathrm{mg} \mathrm{kg}^{-1} \mathrm{dm}$ in caps (Table 6) seems to be an exception. The stipes of Leccinum mushrooms contained around half $\mathrm{Cu}$ compared to the caps (Jarzyńska and Falandysz 2012a, b; J.F., unpublished; Zhang et al. 2012).

In the caps of $M$. procera, the contents of $\mathrm{Cu}$ (many individual samples from background sites) were between 83 and 230 (median) $\mathrm{mgkg}^{-1} \mathrm{dm}$ (Table 6). The Italian
Table 6 Copper in mushrooms (adapted)

A (Falandysz et al. 2008a, 2011; Frankowska et al. 2010; Zhang et al. 2010); B (Giannaccini et al. 2012); C (Li et al. 2011); D (Jarzyńska and Falandysz 2012a); E (Jarzyńska and Falandysz 2012b); F (Falandysz et al. 2007e; Zhang et al. 2013); G (J.F., unpublished); H (Falandysz et al. 2008b; Jarzyńska et al. 2011; Kojta et al. 2011; Gucia et al. 2012a, b); I (Vetter et al. 2005); J (Vetter 2003); K (Györfi et al. 2010)

\begin{tabular}{lllll}
\hline Species & \multicolumn{2}{l}{ Content $\left(\mathrm{mgkg}^{-1} \mathrm{dm}\right)$} & & Ref. \\
\cline { 2 - 4 } & Mean/s $\pm \mathrm{SD}$ & Median/s & Total range & \\
\hline B. edulis (caps) & $26 \pm 11-57 \pm 24$ & $24-79$ & $6.9-94$ & $\mathrm{~A}$ \\
B. edulis (whole) & $28 \pm 14-64 \pm 11$ & 35 & $11-77$ & $\mathrm{~B}$ \\
B. tomentipes (whole) & $14 \pm 1$ & - & $11-14$ & $\mathrm{C}$ \\
L. pseudoscabrum (caps) & $29 \pm 9$ & 27 & $19-48$ & $\mathrm{D}$ \\
L. duriusculum (caps) & $18 \pm 6$ & 16 & $8.4-34$ & $\mathrm{E}$ \\
L. scabrum (caps) & $21 \pm 8-30 \pm 16$ & $20-29$ & $9.1-63$ & $\mathrm{~F}$ \\
L. rufum (caps) & $73 \pm 22-100 \pm 27$ & $45-95$ & $22-150$ & $\mathrm{G}$ \\
M. procera (caps) & $110 \pm 200-200 \pm 60$ & $83-230$ & $52-360$ & $\mathrm{H}$ \\
M. procera (whole) & $120 \pm 23-210 \pm 29$ & 170 & $98-240$ & $\mathrm{~B}$ \\
A. bisporus (caps) & $40 \pm 10$ & - & - & $\mathrm{I}$ \\
A. bisporus (whole) & $58 \pm 2-65 \pm 1$ & - & - & $\mathrm{J}$ \\
A. bisporus (conserved) & $15 \pm 0-15 \pm 1$ & - & - & $\mathrm{J}$ \\
A. subrufescens (caps) & $63 \pm 3-220 \pm 4$ & - & - & $\mathrm{K}$ \\
P. ostreatus (caps) & $19 \pm 9$ & - & - & $\mathrm{I}$ \\
L. edodes (caps) & $13 \pm 2$ & - & - & $\mathrm{I}$ \\
\hline
\end{tabular}


authors examined caps and inedible stipes together (whole fruit bodies), and the $\mathrm{Cu}$ contents were similar as in the caps above, i.e., at 170 (median) $\mathrm{mg} \mathrm{kg}^{-1} \mathrm{dm}$ (Table 6). In stipes of $M$. procera, the contents of $\mathrm{Cu}$ can be the same as in caps or lower (Gucia et al. 2012a). Copper is an essential element and its uptake to some degree can be regulated by the fungus. Data reviewed above on $\mathrm{Cu}$ in B. edulis and $M$. procera are based on large sets of results and mushrooms collected from several sites. The data showed that apart from being statistically significant $(0.05<p<0.01)$, spatial variations were noted for a particular species, while the contents of $\mathrm{Cu}$ can vary between species too. Hence, the significance of a particular species of mushrooms as a potential (and local) source of $\mathrm{Cu}$ to man can vary between regions, while differences in $\mathrm{Cu}$ content between species occur also.

Zinc in B. edulis was reported at between 100 and $210 \mathrm{mg} \mathrm{kg}^{-1} \mathrm{dm}$ (median for caps and whole fruit bodies) and much lower values in $B$. tomentipes (Table 7). The content of $\mathrm{Zn}$ in stipes of $B$. edulis is usually about half or even less than in caps (Falandysz et al. 2008a). Similarly, the stipe of $M$. procera on average contained less $\mathrm{Zn}$, about half the content in the cap (Gucia et al. 2012a). Cultivated $A$. bisporus, $P$. ostreatus, and L. edodes showed less $\mathrm{Zn}$ than $A$. subrufescens and in other wild-grown species reviewed in this paper (Table 7), but the number of data available for cultivated mushrooms is less. The edible wild-grown and cultivated mushrooms can be considered as foods relatively abundant in/with $\mathrm{K}, \mathrm{Cu}$, and $\mathrm{Zn}$, and taking into consideration that these elements are also abundant in many staple foods, clearly there is no need to bio-fortify any mushroom with them.

\section{Selenium and lithium in mushrooms as examples of highly/specifically desired micronutrients}

Selenium is frequently deficient in soils and foods worldwide, and in wild-grown mushrooms, its content varies depending on the species (Falandysz 2008; Rayman 2008; Jarzyńska and Falandysz 2011a, b). This element is highly potent and has great health impacts. It is needed in the synthesis of mammalian selenoenzymes, and glutathione peroxidase-3 and selenoprotein-P are dominant Se compounds secreted in the blood. There are many factors for which Se plays a role, and these need to be considered when deciding on the optimal human supplementation with dietary Se (or its species) including a key co-occurrence in vitamin $\mathrm{E}$ and other antioxidants but also other mineral constituents such as hazardous As, Cd, and Hg (Jarzyńska and Falandysz 2011a, b).

A good bio-available source of Se from foods is needed for the full expression of selenoproteins with antioxidant function and particularly in diseases associated with oxidative stress. Dietary daily intake of Se for humans is recommended at $57 \mu \mathrm{g}$ (range 30-85 $\mu \mathrm{g}$ ), but this sometimes can be insufficient for the expression of selenoprotein-P, and its high adequate intake rate is estimated for approximately 100-200 $\mu \mathrm{g}$ per day (Rayman 2008). The margin of safety for Se is narrow. In the past, overdosing causing selenosis happened to horses (Se poisoning) grazing on Sehyperaccumulating plants and humans eating foods from areas contaminated with Se-containing waste.

Of around 200 edible species reviewed (belonging to 21 families and 56 genera), most were relatively low in Se,
Table 7 Zinc in mushrooms (adapted)

A (Falandysz et al. 2008a, 2011; Frankowska et al. 2010; Zhang et al. 2010); B (Giannaccini et al. 2012); C (Li et al. 2011); D (Jarzyńska and Falandysz 2012a); E (Jarzyńska and Falandysz 2012b); F (Falandysz et al. 2007e; Zhang et al. 2013); G (J.F., unpublished); $\mathrm{H}$ (Falandysz et al. 2008b; Jarzyńska et al. 2011; Kojta et al. 2011; Gucia et al. 2012a, b); I (Vetter et al. 2005); J (Vetter 2003); K (Györfi et al. 2010)

\begin{tabular}{|c|c|c|c|c|}
\hline \multirow[t]{2}{*}{ Species } & \multicolumn{3}{|c|}{ Content $\left(\mathrm{mgkg}^{-1} \mathrm{dm}\right)$} & \multirow[t]{2}{*}{ Ref } \\
\hline & Mean $/ \mathrm{s} \pm \mathrm{SD}$ & Median/s & Total range & \\
\hline B. edulis (caps) & $120 \pm 27-210 \pm 71$ & $110-210$ & $63-360$ & $\mathrm{~A}$ \\
\hline B. edulis (whole) & $74 \pm 6-140 \pm 20$ & 100 & $43-350$ & $\mathrm{~B}$ \\
\hline B. tomentipes (whole) & $20 \pm 1$ & - & $19-23$ & $\mathrm{C}$ \\
\hline L. pseudoscabrum (caps) & $240 \pm 96$ & 210 & $93-420$ & $\mathrm{D}$ \\
\hline L. duriusculum (caps) & $150 \pm 31$ & 150 & $95-200$ & $\mathrm{E}$ \\
\hline L. scabrum (caps) & $110 \pm 24-240 \pm 54$ & $220-250$ & $130-370$ & $\mathrm{~F}$ \\
\hline L. rufum (caps) & $91 \pm 35-240 \pm 91$ & $82-240$ & $41-470$ & G \\
\hline M. procera (caps) & $74 \pm 22-190 \pm 45$ & $73-200$ & $55-240$ & $\mathrm{H}$ \\
\hline M. procera (whole) & $71 \pm 9-200 \pm 8$ & 85 & $61-280$ & $\mathrm{~B}$ \\
\hline A. bisporus (caps) & $65 \pm 10$ & - & - & I \\
\hline A. bisporus (whole) & $60 \pm 0-62 \pm 0$ & - & - & $\mathrm{J}$ \\
\hline A. bisporus (conserved) & $60 \pm 1-86 \pm 4$ & - & - & $\mathrm{J}$ \\
\hline A. subrufescens (caps) & $200 \pm 18-320 \pm 11$ & - & - & $\mathrm{K}$ \\
\hline P. ostreatus (caps) & $77 \pm 3$ & - & - & I \\
\hline L. edodes (caps) & $88 \pm 11$ & - & - & I \\
\hline
\end{tabular}


i.e., $<1 \mathrm{mgkg}^{-1} \mathrm{dm}$ (Falandysz 2008). The fruit bodies of some species of wild-grown edible mushrooms are naturally rich in selenium. Albatrellus pes-caprae with $\sim 200 \mathrm{mg} \mathrm{kg}^{-1}$ $\mathrm{dm}$ on the average (maximum up to $370 \mathrm{mg} \mathrm{kg}^{-1} \mathrm{dm}$ ) is the richest among the species surveyed. Several other representatives of the genus Albatrellus are also abundant in Se. Of the most popular edible wild-grown mushrooms, the $B$. edulis is considered abundant in Se as well; on average, it contains $\sim 20 \mathrm{mg} \mathrm{kg}^{-1} \mathrm{dm}$ (maximum of up to $70 \mathrm{mg} \mathrm{kg}^{-1}$ $\mathrm{dm}$ ). Some species of the genus Boletus, such as Boletus pinophilus, Boletus aereus, Boletus reticulatus, and Boletus erythropus can also accumulate considerable amounts of selenium. Some other species relatively rich in Se include A. strobiliformis, which contains, on average, $\sim 20 \mathrm{mg} \mathrm{kg}^{-1}$ $\mathrm{dm}$ (up to $37 \mathrm{mg} \mathrm{kg}^{-1} \mathrm{dm}$ ), and the Lycoperdon spp., with an average of $\sim 5 \mathrm{mg} \mathrm{kg}^{-1} \mathrm{dm}$ (Falandysz 2008). The mushroom M. procera with a range of $\sim 3-5$ to $<10 \mathrm{mg} \mathrm{Se} \mathrm{kg}{ }^{-1} \mathrm{dm}$ in caps can be also be considered to be rich in this element (Tüzen et al. 2007; Falandysz 2008; Giannaccini et al. 2012).

For several wild-grown species of the genus Agaricus, the selenium content $\left(\sim 5 \mathrm{mgkg}^{-1} \mathrm{dm}\right)$ is much greater than that from cultivated Champignon mushroom; these include Agaricus bitorquis, Agaricus campestris, Agaricus augustus, Agaricus macrosporus, and Agaricus sylvaticus (Falandysz 2008). In cultivated commercially available $A$. bisporus, the contents of Se were between $1.9 \pm 0.1$ and $3.7 \pm 0.9 \mathrm{mgkg}^{-1} \mathrm{dm}$ (Vetter 2003) and $0.28 \pm 0.68$ and $1.4 \pm 0.1 \mathrm{mgkg}^{-1} \mathrm{dm}_{\text {(Costa- }}$ Silva et al. 2011). Canned (preserved) commercially available A. bisporus was much less in $\mathrm{Se}\left(<0.5 \mathrm{mgkg}^{-1} \mathrm{dm}\right)$ compared to fresh mushrooms examined by Vetter (2003). And in recent studies of cultivated $P$. ostreatus from the European market, Se was at $0.10 \pm 0.01$ to $0.26 \pm 0.20 \mathrm{mg} \mathrm{kg}^{-1} \mathrm{dm}$ (Costa-Silva et al. 2011), while the Se content of samples from the USA was $0.2 \mathrm{mgkg}^{-1} \mathrm{dm}$ (Hong et al. 2011).

Different Se compounds can be utilized in the formation of Se enzymes, and the most desired is Se cysteine, which is low in plant or mushroom proteins compared to Se methionine. In mushrooms, several Se compounds have been identified including selenomethionine, selenocysteine, Se methylselenocysteine, selenite, seleno-polysaccharides, and several other unidentified seleno-compounds that occur in varying proportions (Falandysz 2008).

In early attempts to produce Se-enriched edible mushrooms (using A. bisporus and L. edodes), inorganic Se salts were used as additives to the substratum (Falandysz 2008). Compost fortified with inorganic $\mathrm{Se}\left(\mathrm{Na}_{2} \mathrm{SeO}_{3}\right)$ at a rate of 8.1 and $14.4 \mathrm{mgkg}$ has been used, and the Se-enriched Pleurotus eryngii contained, respectively, 4.6 and $9.3 \mathrm{mg}$ Se $\mathrm{kg}^{-1} \mathrm{dm}\left(<1.5 \mathrm{mgkg}^{-1} \mathrm{dm}\right.$ in reference fruit bodies $)$ (Estrada et al. 2009).

Recently, a new approach to obtain Se-enriched foods is by the use of Se-laden vegetation instead of inorganic Se in the cultivation of mushrooms. In a study by Hong et al. (2011), the fruit bodies of $P$. ostreatus emerged in Se-laden plant compost contained $2.9 \mathrm{mg} \mathrm{Se} \mathrm{kg}{ }^{-1} \mathrm{dm}$. In experiments with Pleurotus florida cultivated using Se-rich wheat straw (Se in straw was at $26 \pm 0$, and grains contained $89 \pm 1 \mathrm{mg}$ $\mathrm{kg}^{-1} \mathrm{dm}$ ) from the seleniferous belt of Punjab of India, the Se content of fruit bodies was spectacularly high at $130 \pm$ $2 \mathrm{mg} \mathrm{kg}^{-1} \mathrm{dm}$, and in reference mushrooms, it was $0.16 \pm$ $0.01 \mathrm{mgkg}^{-1} \mathrm{dm}$ (Bhatia et al. 2011).

Also available are data on the impact of boiling/blanching on the Se content of A. bisporus (44\% loss) and in Lactarius torminosus (32\% loss). Data on Se bioavailability from a meal containing B. edulis (weak bioavailability) and cultivated $A$. bisporus and wild-grown $B$. edulis (weak bioavailability) have been reported too. The intake of Seenriched A. bisporus $\left(53 \mathrm{mg} \mathrm{kg}^{-1} \mathrm{dm}\right)$ increased the activities of the liver and mammary glutathione $S$-transferase (GCT) (cited after Falandysz 2008).

In a recent study on the availability of Se to rats that were fed with Se-enriched P. ostreatus (feed contained 0.15, 0.30, or $0.45 \mathrm{mg} \mathrm{Se} \mathrm{kg}^{-1}$ ) and ordinary feed fortified with sodium selenate $\left(0.15 \mathrm{Se} \mathrm{kg}^{-1}\right)$, the profile of some Se-containing proteins in plasma was similar for all animals, while the rate of Se absorption was not given. Selenium from mushroom was the highest in a peptide of $8 \mathrm{kDa}$ size, while the feed with mushroom component resulted in a greatest content of

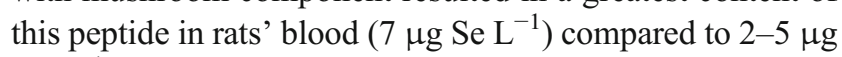
Se $\mathrm{L}^{-1}$ from other diets (Silva et al. 2010).

A mushroom meal that contains $0.005-0.05 \mathrm{mg} \mathrm{Se} \mathrm{kg}^{-1}$ wet weight (many species) when consumed in quantities of 100 or $300 \mathrm{~g}$ - assuming a limited availability of Se from mushrooms (circa 15-25\%) and its loss (circa $40 \%$ ) during mushroom blanching - can provide, respectively, circa 0.66 and $1.8-18 \mu \mathrm{g}$ of bioavailable Se, respectively. Hence, if the values of the recommended daily intake of $57 \mu \mathrm{g} \mathrm{Se}$ (range $30-85 \mu \mathrm{g}$ ) and of high adequate intake of 100 $200 \mu \mathrm{g}$ are taken into account, the species of wild-grown mushrooms rich in Se and also cultivated mushrooms that are well bio-enriched in Se can be considered as good sources of this element for mushroom fanciers. From $B$. edulis and B. reticulatus with an average content of $20 \mathrm{mg}$ Se $\mathrm{kg}^{-1} \mathrm{dm}$, the intake of bioaccessible Se is $24 \mu \mathrm{g}$ (for a 100 -g mushroom portion) and $72 \mu \mathrm{g}$ (for a $300-\mathrm{g}$ portion), and intake from B. pinophilus can be twofold greater. And if Boletus spp. is prepared in a manner allowing only on a negligible if any loss of "body liquid"-and so also of minerals - out of a meal (e.g., a specific Chinese or other cuisine recipes), certainly the intake will be higher. The problem in assessing intake is the fact that the same mushroom species when processed or cooked in various ways, the leakages/leaching of minerals could be anticipated. Also, the contents of minerals in industrially processed mushrooms can vary significantly from what is in fresh 
mushrooms, and a typical example is the data for fresh and preserved A. bisporus (Vetter 2003).

Lithium is a trace mineral in biota, and the lithium salt, $\mathrm{Li}_{2} \mathrm{CO}_{3}$, is therapeutic for neurodisorders (i.e., as a psychiatric medicine) for many years, but a deeper insight of its role has not been discovered. Mushrooms seem to be low in this element. In a study by Vetter (2005), the Li content of 14 taxa of mushrooms was between $0.064 \pm 0.039$ and $0.19 \pm$ $0.13 \mathrm{mg} \mathrm{kg}^{-1} \mathrm{dm}$ and higher amounts were found in $A$. strobiliformis $\left(0.52 \pm 0.55 \mathrm{mgkg}^{-1} \mathrm{dm}\right)$, Craterellus cornucopioides $\left(0.116 \pm 0.70 \mathrm{mg} \mathrm{kg}^{-1} \mathrm{dm}\right)$, and Psathyrella candolleana $\left(0.39 \pm 0.38 \mathrm{mg} \mathrm{kg}^{-1} \mathrm{dm}\right)$. However, entirely different data-with a range from 0.030 to $12 \mathrm{mgkg}^{-1} \mathrm{dm}$ (for some species, only a single result reported as single specimen was examined) - have been reported recently for Russula virescens, Trogia spp., Lactarius hygrophoroides, Thelephora vialis, Russula lepida, Amanita exitialis, and T. matsutake collected in the northern parts of Yunnan in China (Yin et al. 2012). In that study, except for Trogia spp., all other species contained $\mathrm{Li}$ at $>1.0$ and most at $>2.0 \mathrm{mg} \mathrm{kg}^{-1}$ $\mathrm{dm}$, and this needs to be clarified in further studies.

In a study by Giannaccini et al. (2012), the Li content of B. edulis was at $0.2 \pm 0.2$ (median 0.1 and range 0.04-0.9) $\mathrm{mgkg}^{-1} \mathrm{dm}$ and of M. procera at $0.3 \pm 0.4$ (median 0.1 and range $0.03-1.6) \mathrm{mg} \mathrm{kg}^{-1} \mathrm{dm}$, and these results agree with the findings for other mushrooms cited above as reported by Vetter (2005). In the only study on bio-enrichment of mushrooms with Li known, the species $P$. ostreatus cultivated in the substratum (coffee husk; $94 \mathrm{mg} \mathrm{Li} \mathrm{kg}{ }^{-1} \mathrm{dm}$ ) fortified with $\mathrm{LiCl}\left(62.5\right.$ to $\left.500 \mathrm{mg} \mathrm{kg}^{-1}\right)$ accumulated this element in fruit bodies and as the authors claim: " $\mathrm{Li}$ concentration in mushrooms was directly influenced by increasing $\mathrm{LiCl}$ concentration in the substrate $(p<0.05)$ " (Assunção et al. 2012). However, the Li content of nonenriched P. ostreatus in that study was around $50 \mathrm{mgkg}^{-1} \mathrm{dm}$ (no clear figures were given), and this is about the highest $\mathrm{Li}$ concentration reported for mushrooms so far. One thing noticed, however, is that the accessibility (in vitro gastrointestinal digestion) of Li was higher from bio-enriched mushrooms than from common (nonenriched) mushrooms and, in practice, is not acceptable for use in psychiatric drug $\left(\mathrm{Li}_{2} \mathrm{CO}_{3}\right)$ (Assunção et al. 2012).

\section{Toxic mineral constituents in mushrooms $(\mathrm{Hg}, \mathrm{As}, \mathrm{Cd}$, $\mathrm{Pb}$, Ag)}

Among the hazardous minerals that occur naturally in substrates decomposed by fungi and in the flesh of mushrooms are $\mathrm{Hg}, \mathrm{As}, \mathrm{Cd}, \mathrm{Pb}$, and $\mathrm{Ag}$. Metallic elements such as $\mathrm{Hg}$, $\mathrm{Cd}, \mathrm{Pb}$, and $\mathrm{Ag}$ and the metalloid $\mathrm{As}$, and other, due to mining, metallurgy, use, wastes, and recovery processes, are classified as environmental pollutants. Elevated contents of
$\mathrm{Hg}, \mathrm{Cd}, \mathrm{Pb}$, and $\mathrm{Ag}$ in mushrooms were confirmed at polluted sites (see below).

Mercury can be efficiently bioaccumulated by many mushrooms and especially when it is present in small concentrations in forest soils, e.g., for caps of M. procera, the BAF values vary from $16 \pm 6$ to $220 \pm 110$ (total range from 0.52 to 470 ), and for $B$. edulis, these were from $41 \pm 6$ to 130 \pm 39 (total variation between 13 and 170) (Falandysz et al. 2007a; Falandysz and Gucia 2008). The problem of $\mathrm{Hg}$ in mushrooms has been evaluated in detail for many species from different countries in recent times (Falandysz and Chwir 1997; Falandysz 2002; Falandysz and Bielawski 2001, 2007; Alonso et al. 2000; Falandysz et al. 2001a, 2002a, b, c, d, 2003a, b, c, d, 2004, 2007a, b, f, 2012c, d, e, f, 2013; Tüzen and Soylak 2005; Cocchi et al. 2006; Falandysz and Brzostowski 2007; Chudzyński et al. 2009, 2011; Melgar et al. 2009; Nasr and Arp 2011; Pilz et al. 2011; Reider et al. 2011; Chojnacka et al. 2012; Drewnowska et al. 2012a, b; Giannaccini et al. 2012; Maćkiewicz and Falandysz 2012; Nnorom et al. 2012a).

Data on the rates of highly neurotoxic methylmercury (MeHg) bioaccumulation by mushrooms vary between studies, and some have shown that it is a form more bioavailable compared to inorganic forms (considered as "total" $\mathrm{Hg}$ ). $\mathrm{MeHg}$ is less abundant than the inorganic $\mathrm{Hg}$, both in the wild-growing and cultivated mushrooms, i.e., it is found between $\sim 2$ and $60 \%$ of total $\mathrm{Hg}$, though the proportions vary depending on the investigator, concentration, and analytical method (Table 8) (Falandysz 2010; Fischer et al. 1995; Pilz et al. 2011; Reider et al. 2011).

Mushrooms B. edulis and M. procera even when they emerged at background sites in Italy, Poland, and Spain can contain total $\mathrm{Hg}$ at elevated concentrations, i.e., for caps, was at $1.2 \pm 1.4$ to $7.6 \pm 3.1$ (total range 0.02 to 14 ) $\mathrm{mgkg}^{-1}$ $\mathrm{dm}$ and, for whole fruit bodies, at $1.2 \pm 0.7$ to $8.4 \pm 7.4(0.05$ to 22) $\mathrm{mg} \mathrm{kg}^{-1} \mathrm{dm}$, respectively (Falandysz et al. 2007a, b; Melgar et al. 2009; Giannaccini et al. 2012). They can be a source of elevated $\mathrm{Hg}$ intake. For example, in a study of $M$. procera, the median $\mathrm{Hg}$ concentration in caps varied for the sites between 1.3 and $7.0 \mathrm{mg} \mathrm{kg}^{-1} \mathrm{dm}\left(0.13\right.$ and $0.7 \mathrm{mg} \mathrm{kg}^{-1}$ fresh weight; assuming water content is $90 \%$ ). The estimated intake of $\mathrm{Hg}$ resulting from the consumption of 300 or $500 \mathrm{~g}$ portions of caps was assessed as $39-210$ and 65$350 \mu \mathrm{g}$, and this is equivalent to $0.65-3.5$ and $1.1-5.8 \mu \mathrm{g}$ $\mathrm{kg}^{-1}$ body mass (an adult of $60 \mathrm{~kg} \mathrm{bm}$ ) (Gucia et al. 2012b). It was concluded, that if taken into account, that provisionally tolerable weekly intake (PTWI) of $\mathrm{Hg}$ is $300 \mu \mathrm{g}$ (equivalent to 5 or $0.7 \mu \mathrm{g} \mathrm{kg}^{-1}$ bm per day), and a reference dose of $0.3 \mu \mathrm{g} \mathrm{kg}^{-1} \mathrm{bm}$ per day, $\mathrm{Hg}$ in caps of $M$. procera for some pristine areas might be of concern especially if eaten by fanciers frequently in the mushrooming season.

Both $B$. edulis and of $M$. procera apart from $\mathrm{Hg}$ can also contain Se (especially B. edulis) at high concentrations (see 
Table 8 Mercury in mushrooms (adapted)

A (Falandysz et al. 2007a, 2011; Frankowska et al. 2010; Zhang et al. 2010); B (Cocchi et al. 2006); C (Giannaccini et al. 2012); D (Melgar et al. 2009); E (Falandysz et al. 2007b; Falandysz and Gucia 2008); F (Jarzyńska and Falandysz 2012a); G (Jarzyńska and Falandysz 2012b); H (Falandysz et al. 2007e); I (Falandysz et al. 2012d)

$h$ hynenophore, $r f b$ rest of fruit body

${ }^{\mathrm{a}} 95 \%$ confidence interval

\begin{tabular}{|c|c|c|c|c|}
\hline \multirow[t]{2}{*}{ Species } & \multicolumn{3}{|l|}{ Content $\left(\mathrm{mgkg}^{-1} \mathrm{dm}\right)$} & \multirow[t]{2}{*}{ Ref } \\
\hline & Mean $/ \mathrm{s} \pm \mathrm{SD}$ & Median/s & Total range & \\
\hline B. edulis (caps) & $1.2 \pm 1.4-7.6 \pm 3.1$ & $0.73-6.3$ & $0.02-14$ & A \\
\hline B. edulis (whole) & 2.7 & - & $1.0-4.3^{\mathrm{a}}$ & $\mathrm{B}$ \\
\hline B. edulis (whole) & $1.9 \pm 1.0-4.5 \pm 1.0$ & $1.9-4.6$ & $1.0-6.1$ & $\mathrm{C}$ \\
\hline B. edulis (h/rfb) & $3.3 \pm 2.4 / 2.0 \pm 1.2$ & - & - & $\mathrm{D}$ \\
\hline M. procera (caps) & $1.1 \pm 1.0-8.4 \pm 7.4$ & $1.3-7.4$ & $0.05-22$ & $\mathrm{E}$ \\
\hline M. procera (whole) & 2.4 & - & $1.5-3.3^{\mathrm{a}}$ & $\mathrm{B}$ \\
\hline M. procera (whole) & $1.4 \pm 0.3-4.0 \pm 0.2$ & $1.6-4.0$ & $1.4-4.2$ & $\mathrm{C}$ \\
\hline M. procera $(\mathrm{h} / \mathrm{rfb})$ & $2.6 \pm 1.2 / 1.6 \pm 0.7$ & - & - & $\mathrm{D}$ \\
\hline L. pseudoscabrum (caps) & $0.34 \pm 0.17$ & 0.33 & $0.12-0.65$ & $\mathrm{~F}$ \\
\hline L. scabrum (caps) & $0.38 \pm 0.23-1.2 \pm 0.4$ & $0.36-1.2$ & $0.072-2.0$ & $\mathrm{H}$ \\
\hline L. scabrum $(\mathrm{h} / \mathrm{rfb})$ & $0.57 \pm 0.23 / 0.44 \pm 0.31$ & - & - & $\mathrm{D}$ \\
\hline L. rufum (caps) & $0.27 \pm 0.07-1.3 \pm 0.6$ & $0.28-1.3$ & $0.16-2.2$ & I \\
\hline
\end{tabular}

above), and this can have protective roles against $\mathrm{Hg}$ in biological activity but no facts are known. The accessibility and bioavailability of $\mathrm{Hg}$ from mushroom meals is unknown.

Wood-decaying mushroom species are low in $\mathrm{Hg}$ compared to the numerous soil mushrooms, and good examples are Pleurotus spp. with P. ostreatus containing between $0.028 \pm$ 0.008 and $0.031 \pm 0.011$ in caps and $0.028 \pm 0.006$ and $0.0370 \pm$ $0.005 \mathrm{mgkg}^{-1} \mathrm{dm}$ in stipes (Nnorom et al. 2012a). The sclerotia of wood-decaying $P$. tuber-regium are low in $\mathrm{Hg}$ and did contain from $0.024 \pm 0.036$ to $0.048 \pm 0.030 \mathrm{mgkg}^{-1} \mathrm{dm}$ (Nnorom et al. 2012a). Also wood-decaying species such as A. solidipes that has of root-like rhizomorphs (tentacles, bootlaces) can be more abundant in $\mathrm{Hg}$ - specimens collected from two background areas of Poland showed $\mathrm{Hg}$ in caps of $0.020 \pm$ 0.008 to $0.070 \pm 0.020 \mathrm{mgkg}^{-1} \mathrm{dm}$, on average, and significantly more, i.e., between $0.11 \pm 0.03$ and $0.30 \pm 0.07 \mathrm{mg} \mathrm{kg}^{-1} \mathrm{dm}$ was observed for specimens from ten other background sites (Falandysz et al. 2012e).

Arsenic in a real environment (nature) is the most hazardous inorganic element due to the carcinogenic risk, and there are no safe levels of arsenic. Different mushrooms can respond in different ways for the same chemical elements contained in the substratum where they live and a good example seems to be just a case of As. Many mushrooms are usually low in As (well $<0.5 \mathrm{mg} \mathrm{kg}^{-1} \mathrm{dm}$ ) (Stijve et al. 1990; Giannaccini et al. 2012; Li et al. 2011; Liu et al. 2012). Some mushrooms are specifically rich in this metalloid, i.e., Laccaria amethystina with up to $250 \mathrm{mgkg}^{-1} \mathrm{dm}$ and Laccaria fraterna with up to $270 \mathrm{mgkg}^{-1} \mathrm{dm}$ (Stijve et al. 1990). Arsenic in S. coronaria can be at concentrations of up to $2,000 \mathrm{mg} \mathrm{kg}^{-1} \mathrm{dm}$ and is stored mainly in the form of methylarsonic acid (Byrne et al. 1995). Arsenic accumulated by L. amethystina in the flesh was in the form of dimethylarsinic acid (the most identified form), methylarsonic acid, trimethylarsine oxide, arsenic acid, and arsenobetaine and insoluble in water and unidentified arsenicals contributed to total As in 15 to $32 \%$ (Larsen et al. 1998; Stijve et al. 1990). At a site contaminated with As in Denmark, the metalloid content of L. amethystina was up to $1,400 \mathrm{mg} \mathrm{kg}^{-1} \mathrm{dm}$ and dimethylarsinic acid dominated (at $68-74 \%$ of total As) and the As content of L. amethystina at a reference site was between 23 and $77 \mathrm{mg} \mathrm{kg}^{-1} \mathrm{dm}$ (Larsen et al. 1998).

Mushrooms that bioaccumulate As include Sarcodon imbricatus, Entoloma lividum, Lycoperdon perlatum, and some Agaricus spp. (Byrne et al. 1995). Arsenobetaine that is the major As compound in S. imbricatus, A. sylvaticus, and $A$. moelleri is considered much less toxic than many other naturally occurring types of arsenic. In E. lividum, the major arsenicals are the arsenite and the arsenate (Byrne et al. 1995). At the gold mine site contaminated with As in Yellowknife of Canada, the metalloid content of non-As accumulators was elevated, i.e., at $8.3 \mathrm{mgkg}^{-1} \mathrm{dm}$ in $L$. scabrum, $14 \mathrm{mgkg}^{-1} \mathrm{dm}$ in Psathyrella candolleana, and $36 \mathrm{mgkg}^{-1} \mathrm{dm}$ in P. involutus (Koch et al. 2000). In two other species, potential As accumulators, the concentrations were $410 \mathrm{mg} \mathrm{kg}^{-1} \mathrm{dm}$ in C. comatus and $1,000 \mathrm{mg} \mathrm{kg}^{-1} \mathrm{dm}$ in Lycoperdon pyriforme. In certain mushrooms, arsenobetaine was dominant as water-soluble arsenic compound, while in other species several compounds have been found and the proportions of arsenicals contained varied between them (Koch et al. 2000).

Cultivated $A$. bisporus when they emerge at the substratum fortified with as much as 1,000 mg As kg-1 $\mathrm{dm}^{-}$(added as $\mathrm{As}_{2} \mathrm{O}_{5}$ ) weakly accumulated this metalloid, i.e., the value of BAF was 0.0009 . In a control experiment, $A$. bisporus cultivated in a typical (clean) substratum that contained $3.8 \mathrm{mg}$ As $\mathrm{kg}^{-1} \mathrm{dm}$ [several As(III) and As(V) compounds were determined] contained in the flesh $0.50 \mathrm{mg} \mathrm{As} \mathrm{kg}{ }^{-1} \mathrm{dm}$, and BAF for total As was 0.13 (Soeroes et al. 2005). Cultivated 
mushrooms such as $A$. bisporus, Agaricus spp., P. ostreatus, $P$. florida, P. eryngii, P. ostreatus, Pleurotus salmoneostramineus, and L. edodes purchased in Brazil contained As in concentrations between 0.009 and $0.210 \mathrm{mg} \mathrm{kg}^{-1} \mathrm{dm}$ (Maihara et al. 2008).

Cadmium as indicated earlier is well bioaccumulated and can be found at elevated concentrations in wild-grown mushrooms. This metal in the flesh of edible wild mushrooms is among the toxic substances of concern. The maximum concentration of $\mathrm{Cd}$ permitted by the European Union regulation in cultivated $A$. bisporus, $P$. ostreatus, and $L$. edodes is $0.20 \mathrm{mg} \mathrm{kg}^{-1} \mathrm{fw}$ (equivalent to $2.0 \mathrm{mg} \mathrm{kg}^{-1} \mathrm{dm}$, assuming $90 \%$ moisture), and for other mushrooms, it is $1.0 \mathrm{mgkg}^{-1}$ fw $\left(10 \mathrm{mgkg}^{-1} \mathrm{dm}\right.$ ) (cited after Gucia et al. 2012b).

Wild-grown mushrooms frequently contain $\mathrm{Cd}$ in a concentration exceeding $2.0 \mathrm{mg} \mathrm{kg}^{-1} \mathrm{dm}$ but rarely above $10 \mathrm{mg}$ $\mathrm{kg}^{-1} \mathrm{dm}$. An example is the highly valued and tasty $B$. edulis and $M$. procera mushrooms for which several data are available and for numerous and also for some species of the genus Leccinum (Table 9). Cadmium concentration exceeding $10 \mathrm{mg} \mathrm{kg}^{-1} \mathrm{dm}$ can be observed for a few individual samples at unpolluted areas, but at areas contaminated with $\mathrm{Cd}$, this threshold can be exceeded frequently.

Cultivated mushrooms such as $A$. bisporus, $P$. ostreatus, and $L$. edodes from Hungary showed $\mathrm{Cd}$ in caps of $0.17 \pm$ $0.13,0.91 \pm 0.32$, and $0.71 \pm 0.48 \mathrm{mgkg}^{-1} \mathrm{dm}$ (Vetter et al. 2005), and this is at the lower edge of the average $\mathrm{Cd}$ concentrations noted in some wild-grown species (Table 9). The reported $\mathrm{Cd}$ contents of $A$. bisporus, Agaricus spp., P. ostreatus, P. florida, P. eryngii, P. salmoneo-stramineus, and L. edodes on sale (or purchased) in Brazil are 0.011 to $0.23 \mathrm{mg} \mathrm{kg}^{-1} \mathrm{dm}$, and these are only weakly contaminated (Maihara et al. 2008). Surprisingly high concentration of $\mathrm{Cd}$ with an average value of $10 \pm$ $1 \mathrm{mg} \mathrm{kg}^{-1} \mathrm{dm}$, which exceeds the European Union limit of $2.0 \mathrm{mg} \mathrm{kg}^{-1} \mathrm{dm}$ by fivefold (see below), has been noted in the fruit bodies of commercially cultivated Agaricus blazei bought at a market in Kunming (Yunnan, China) (Sun et al. 2012). The PTWI set by the Joint FAO/WHO Expert Committee on Food Additives for $\mathrm{Cd}$ is $7 \mathrm{mg} \mathrm{kg}^{-1} \mathrm{bm}$ (equivalent to $1 \mathrm{mg} \mathrm{kg}^{-1} \mathrm{bm}$ per day) (from Gucia et al. $2012 \mathrm{~b}$ ), and a tolerable weekly intake (TWI) of $2.5 \mu \mathrm{g} / \mathrm{kg}$ bw (equivalent to $0.36 \mathrm{mg} \mathrm{kg}^{-1}$ bm per day) was established by EFSA (from Gucia et al. 2012b).

$M$. procera is a mushroom with a large size and its caps are highly valued by mushrooming fanciers. In one study, Cd intake resulting from the consumption of a $300-$ or $500-\mathrm{g}$ portion of caps of $M$. procera was estimated as 4.7-111 and 24.5-185 $\mu \mathrm{g}$ (median Cd content between 0.049 and 0.37 $\mathrm{mg} \mathrm{kg}^{-1} \mathrm{fw}$, assuming water content of $90 \%$ ), and these are equivalent to $0.078-1.85$ and $0.41-3.1 \mathrm{\mu gkg}^{-1} \mathrm{bm}$ (for an adult of $60 \mathrm{~kg} \mathrm{bm}$ ) (Gucia et al. 2012b). It was concluded in this study by Gucia et al. (2012b) that in a good "mushroom" year, the consumption of large quantities of $M$. procera will lead to a short time ( 2 weeks to up to 2 months) exposure of fanciers to elevated $\mathrm{Cd}$ doses that exceeded the PTWI and TWI recommendations. Hence, $\mathrm{Cd}$ in caps of $M$. procera at some of the sites surveyed might be of concern to consumers, if eaten frequently by an individual in the mushrooming season.

Cadmium is among the minerals leached out of fruit bodies during boiling. The boiling and microwaving, with water, of $A$. blazei reduces its $\mathrm{Cd}$ content by 36 and $30 \%$, respectively (Sun et al. 2012). Accessibility of $\mathrm{Cd}$ from mushroom meals is more or less limited (cited after Gucia et al. 2012b). Accessibility of Cd from raw A. blazei will be greater $(78 \%$ by stomach and $69 \%$ by gastrointestinal mimetic digestion) compared to when the mushrooms are boiled (51 and $46 \%$ ) and microwaved (58 and $50 \%$ ) (Sun et al. 2012). It should be noted that we do not recommend eating of any mushroom raw, and one of the reasons is agaritin, which is a phenylhydrazine derivative present in mushrooms of the genus Agaricus and that is hazardous to
Table 9 Cadmium in mushrooms (adapted)

A (Falandysz et al. 2008a, 2011; Frankowska et al. 2010; Zhang et al. 2010); B (Cocchi et al. 2006); C (Giannaccini et al. 2012); D (Jarzyńska et al. 2011; Kojta et al. 2011; Gucia et al. 2012a, b); D (Jarzyńska and Falandysz 2012a); E (Jarzyńska and Falandysz 2012b); F (Falandysz et al. 2007e; Zhang et al. 2013); G (J.F., unpublished)

${ }^{\mathrm{a}} 95 \%$ confidence interval

\begin{tabular}{lllll}
\hline Species & \multicolumn{2}{l}{ Content $\left(\mathrm{mgkg}^{-1} \mathrm{dm}\right)$} & & Ref. \\
\cline { 2 - 4 } & Mean/s $\pm \mathrm{SD}$ & Median/s & Total range & \\
\hline B. edulis (caps) & $3.8 \pm 2.8-18 \pm 15$ & $2.6-11$ & $0.23-52$ & $\mathrm{~A}$ \\
B. edulis (whole) & 4.0 & - & $3.0-4.9^{\mathrm{a}}$ & $\mathrm{B}$ \\
B. edulis (whole) & $2.0 \pm 1.6-3.4 \pm 1.8$ & $1.6-3.4$ & $0.5-5.3$ & $\mathrm{C}$ \\
M. procera (caps) & $0.63 \pm 0.20-4.9 \pm 3.0$ & $0.49-3.7$ & $0.28-11$ & $\mathrm{D}$ \\
M. procera (whole) & 1.3 & - & $0.77-1.0^{\mathrm{a}}$ & $\mathrm{B}$ \\
M. procera (whole) & $0.7 \pm 0.3-7.6 \pm 0.5$ & $0.7-7.8$ & $0.3-7.9$ & $\mathrm{C}$ \\
L. pseudoscabrum (caps) & $3.3 \pm 2.1$ & 2.9 & $1.1-8.5$ & $\mathrm{D}$ \\
L. duriusculum (caps) & $1.5 \pm 0.5$ & 1.3 & $0.80-2.9$ & $\mathrm{E}$ \\
L. scabrum (caps) & $3.3 \pm 2.7-6.6 \pm 3.2$ & $2.4-5.7$ & $0.42-14$ & $\mathrm{~F}$ \\
L. rufum (caps) & $0.36 \pm 0.25-4.5 \pm 5.6$ & $0.30-1.6$ & $0.08-21$ & $\mathrm{G}$ \\
\hline
\end{tabular}


human health (Andersson and Gry 2004). Agaritin is deactivated when mushrooms are heat-cooked.

Lead as discussed earlier is excluded in mushrooms $(\mathrm{BAF}<1)$, but this toxic metallic element compared to $\mathrm{Cd}$ or $\mathrm{Hg}$ is more abundant in the top layers of forest soils. For example, $\mathrm{Pb}$ in the top layer of soils beneath $B$. edulis and/or $M$. procera in the mountain areas of Tuscany of Italy was at 26 to $47 \mathrm{mg} \mathrm{kg}^{-1} \mathrm{dm}$ (Giannaccini et al. 2012), at 6.7 to $37 \mathrm{mgkg}^{-1} \mathrm{dm}$ in Tucholskie forests of Poland (Jarzyńska et al. 2011), and 26 to $270 \mathrm{mg} \mathrm{kg}^{-1} \mathrm{dm}$ in the top soil beneath $X$. badius at the forested mine dump site of a medieval gold and copper mine in Sudety mountains (Kojta et al. 2012). Hence, even if the potential to bioaccumulate $\mathrm{Pb}$ by species is low $(\mathrm{BAF}<1)$, a quantity of $\mathrm{Pb}$ sequestered in the flesh by a small portion of mushrooms that emerged at "unpolluted" sites can ordinarily be of health concern (Table 10), but metal accessibility from this type of food is unknown. The maximum concentration of $\mathrm{Pb}$ permitted by the European Union regulation in cultivated $A$. bisporus, P. ostreatus, and L. edodes is $0.3 \mathrm{mg} \mathrm{kg}^{-1} \mathrm{fw}$ (equivalent to $3.0 \mathrm{mg} \mathrm{kg}^{-1} \mathrm{dm}$, assuming $90 \%$ moisture) (cited after Gucia et al. 2012b).

In a recent study, the concentrations of $\mathrm{Pb}$ in hymenophore and the rest of the fruit body of such edible but probably not frequently eaten species such as $C$. comatus, A. campestris, and Lepista nuda were at 3.6 and 4.1, 3.0 and 2.2, and 2.5 and $2.3 \mathrm{mg} \mathrm{kg}^{-1} \mathrm{dm}$ (no statistical difference between those morphological parts was noted) (García et al. 2009). In cultivated species, $\mathrm{Pb}$ concentrations were mostly low, below $3.0 \mathrm{mg} \mathrm{kg}^{-1} \mathrm{dm}$, and examples are data from Mexico where A. bisporus (caps) contained on average $0.41 \mathrm{mgkg}^{-1} \mathrm{dm}$ and P. ostreatus (whole) $0.91 \mathrm{mgkg}^{-1} \mathrm{dm}$, while the spread of data for both species from reports on global scale is wide (Muñoz et al. 2005).
The acceptable daily intake of $\mathrm{Pb}$ for adults is between 0.21 and $0.25 \mathrm{mg}$ per day and 1.5 and $1.75 \mathrm{mg}$ per week (from Jarzyńska and Falandysz 2011a, b). In the case of $M$. procera, the estimated $\mathrm{Pb}$ intake from consumption of 300 or $500 \mathrm{~g}$ caps was $42-267$ and $70-445 \mu \mathrm{g}$ per meal, respectively. These values were based on the median concentrations of $\mathrm{Pb}$ found. It was concluded that, at some sites, the $\mathrm{Pb}$ intake rates show a cause for concern associated with $\mathrm{Pb}$ resulting from the consumption of between 300 and $500 \mathrm{~g}$ caps daily, on a frequent basis in the mushrooming season (Gucia et al. 2012b).

Silver is toxic to animal cells and $\mathrm{Ag}^{+}$ion is highly toxic to bacteria. This is because $\mathrm{Ag}$ ion has a high affinity for sulfhydryl, amino, and phosphate groups, and it readily complexes with many endogenous ligands of the mammalian body. As given earlier, Ag at background and in geoanomalous and contaminated areas is very efficiently bioaccumulated by many mushrooms (Borovička et al. 2007, 2010b; Falandysz et al. 1994a, b; Falandysz and Danisiewicz 1995; Kojta et al. 2012). Data on $\mathrm{Ag}$ in several mushrooms from areas with $\mathrm{Ag}$ anomaly can be found in the article by Borovička et al. (2010b).

Apart from hyperaccumulators of this element (see above), it can be found at elevated contents in popular species, e.g., M. procera that were collected from background areas contained up to $4.8 \mathrm{mg} \mathrm{kg}^{-1} \mathrm{dm}$ (median value) (Table 11). Silver was found also in cultivated A. bisporus (Table 11), but the number of available data for cultivated mushrooms seems to be very limited. To our knowledge, no data were published on the accessibility of Ag from mushrooms (cooked) to man, and the content of this metal in foods is not regulated.
Table 10 Lead in mushrooms (adapted)

A (Falandysz et al. 2008a); B

(Cocchi et al. 2006); C

(Giannaccini et al. 2012); D

(García et al. 2009); E

(Jarzyńska et al. 2011; Kojta et al. 2011; Gucia et al. 2012a, b); F (Jarzyńska and Falandysz 2012a); G (Jarzyńska and Falandysz 2012b); H (Falandysz et al. 2007e; Zhang et al. 2013); I (J.F., unpublished)

$h$ hynenophore, $r f b$ rest of fruit body

${ }^{\mathrm{a}} 95 \%$ confidence interval

\begin{tabular}{|c|c|c|c|c|}
\hline \multirow[t]{2}{*}{ Species } & \multicolumn{3}{|l|}{ Content $\left(\mathrm{mgkg}^{-1} \mathrm{dm}\right)$} & \multirow[t]{2}{*}{ Ref. } \\
\hline & Mean $/ \mathrm{s} \pm \mathrm{SD}$ & Median/s & Total range & \\
\hline B. edulis (caps) & $0.51 \pm 0.19-2.0 \pm 0.9$ & $0.22-0.94$ & $0.10-2.9$ & A \\
\hline B. edulis (whole) & 1.2 & - & $0.37-2.1^{\mathrm{a}}$ & $\mathrm{B}$ \\
\hline B. edulis (whole) & $0.8 \pm 0.3-2.6 \pm 0.8$ & $0.9-2.8$ & $0.4-3.4$ & $\mathrm{C}$ \\
\hline B. edulis $(\mathrm{h} / \mathrm{rfb})$ & $0.70 \pm 0.30 / 0.72 \pm 0.30$ & - & - & $\mathrm{D}$ \\
\hline M. procera (caps) & $1.3 \pm 0.5-8.5 \pm 2.4$ & $1.3-8.9$ & $0.02-18$ & $\mathrm{E}$ \\
\hline M. procera (whole) & 3.4 & - & $2.2-4.7$ & $\mathrm{~B}$ \\
\hline M. procera (whole) & $0.9 \pm 0.3-10 \pm 4$ & $0.9-8.7$ & $0.7-15$ & $\mathrm{C}$ \\
\hline M. procera $(\mathrm{h} / \mathrm{rfb})$ & $1.8 \pm 1.6 / 1.2 \pm 0.7$ & - & - & $\mathrm{D}$ \\
\hline L. pseudoscabrum (caps) & $0.53 \pm 0.28$ & 0.42 & $0.18-1.1$ & $\mathrm{~F}$ \\
\hline L. duriusculum (caps) & $0.36 \pm 0.14$ & 0.35 & $0.14-0.69$ & G \\
\hline L. scabrum (caps) & $0.56 \pm 0.23-4.1 \pm 4.2$ & $0.52-3.0$ & $0.22-16$ & $\mathrm{H}$ \\
\hline L. scabrum $(\mathrm{h} / \mathrm{rfb})$ & $1.2 \pm 0.5 / 1.4 \pm 0.5$ & - & - & $\mathrm{D}$ \\
\hline L. rufum (caps) & $0.26 \pm 0.16-1.2 \pm 1.2$ & $0.19-0.76$ & $0.06-5.0$ & I \\
\hline
\end{tabular}


Table 11 Silver in mushrooms (adapted)

A (Falandysz et al. 1994a; 2008a); B (Falandysz et al. 1994a); C (Falandysz et al. 2008b; Jarzyńska et al. 2011; Kojta et al. 2011; Gucia et al. 2012a, b); D (Jarzyńska and Falandysz 2012a); E (Jarzyńska and Falandysz 2012b); H (Falandysz et al. 1994a, 2007e; Zhang et al. 2013); I (Falandysz et al. 1994a; J.F., unpublished); J (Falandysz et al. 1994a); K (Falandysz et al. 1994b)

\begin{tabular}{lllll}
\hline \multirow{2}{*}{ Species } & \multicolumn{2}{l}{ Content $\left(\mathrm{mgkg}^{-1} \mathrm{dm}\right)$} & & \multirow{2}{*}{ Ref. } \\
\cline { 2 - 4 } & \multicolumn{1}{l}{ Mean/s $\pm \mathrm{SD}$} & Median/s & Total range & \\
\hline B. edulis (caps) & $0.51 \pm 0.19-2.0 \pm 0.9$ & $0.22-0.94$ & $0.48-22$ & $\mathrm{~A}$ \\
B. edulis (whole) & $0.68 \pm 0.94$ & - & $0.16-2.6$ & $\mathrm{~B}$ \\
M. procera (caps) & $0.10 \pm 0.22-5.5 \pm 3.4$ & $0.05-4.8$ & $0.01-12$ & $\mathrm{C}$ \\
L. pseudoscabrum (caps) & $0.57 \pm 0.15$ & 0.52 & $0.40-0.96$ & $\mathrm{D}$ \\
L. duriusculum (caps) & $0.93 \pm 0.24$ & 0.86 & $0.58-1.4$ & $\mathrm{E}$ \\
L. scabrum (caps) & $0.47 \pm 0.64-0.76 \pm 0.35$ & $0.45-0.78$ & $0.12-1.9$ & $\mathrm{H}$ \\
L. rufum (caps) & $0.12 \pm 0.04-0.93 \pm 0.35$ & $0.11-0.93$ & $0.03-1.6$ & $\mathrm{I}$ \\
L. versipelle & $0.27 \pm 0.03$ & - & $0.22-0.29$ & $\mathrm{~J}$ \\
L. vulpinum & $2.0 \pm 0.6$ & - & $1.5-3.1$ & $\mathrm{~J}$ \\
A. bisporus (caps) & $0.55 \pm 0.14$ & - & $0.42-0.79$ & $\mathrm{~K}$ \\
A. bisporus (whole) & $0.30 \pm 0.07-0.46 \pm 0.09$ & - & $0.15-0.58$ & $\mathrm{~K}$ \\
\hline
\end{tabular}

\section{Radioactivity of mushrooms}

Wild-grown mushrooms in several reports are described as biota that are efficient accumulators and bioindicators of environmental diffusion of radionuclides. Emphasis is frequently given on long-lived ${ }^{137} \mathrm{Cs}$ that polluted the surface of the Earth due to global radioactive fallout after testing of nuclear weapons and from nuclear power plant accidents, but some others as well as naturally occurring radionuclides are also intensively studied in mushrooms (Horyna and Řanda 1988; Bakken and Olsen 1990; Tsvetnova and Shcheglov 1994; Dahlberg et al. 1997; Kirchner and Daillant 1998; Rühm et al. 1997; Skwarzec and Jakusik 2003; Strandberg 2004; Baeza et al. 2004a, b; Kostiainen 2007; Vaartamaa et al. 2009; Mietelski et al. 2002, 2010; Taira et al. 2011; Vinichuk et al. 2011; Castro et al. 2012; and many others).

The capacity of mushrooms to sequester radioactive elements in fruit bodies and so the rates of their uptake vary between species, and good examples to illustrate this are data on the contents of the most studied- ${ }^{137} \mathrm{Cs}$. There is no reason for mushrooms to discriminate between stable and radioactive isotopes of elements when absorbed by the mycelium and accumulated in the mushroom flesh, but their accessibility at sites where the mycelium lives can be different. There are several types of radioactivity, and the decay of elements results in the emission of extremely toxic subatomic particles such as alpha $(\alpha)$ particle (helium nuclei, i.e., two protons, $\mathrm{He}^{2+}$ ) and less potent beta minus (energetic electrons, $\beta$ ) and beta plus $\left(\beta^{+}\right.$, positrons) particles and also of gamma $(\gamma)$ ray (photon) with nuclide's half-life $\left(T_{1 / 2}\right)$ equivalent respectively from several days to millions of years (Skwarzec 2012).

Some of the radioactive elements naturally occurring in nature that are the primordial non-series radionuclides of terrestrial (e.g., ${ }^{40} \mathrm{~K}$ and ${ }^{87} \mathrm{Rb}$ ) and cosmogenic origin (e.g., $\left.{ }^{3} \mathrm{H},{ }^{7} \mathrm{Be},{ }^{14} \mathrm{C},{ }^{22} \mathrm{Na}\right)$ and that of uranium $\left({ }^{238} \mathrm{U}\right)$, thorium $\left({ }^{232} \mathrm{Th}\right)$, actino-uranium $\left({ }^{235} \mathrm{U}\right)$, and neptunium $\left({ }^{237} \mathrm{~Np}\right)$ decay series have been found in mushrooms, but published data are few (see below). The cosmogenic ${ }^{3} \mathrm{H},{ }^{7} \mathrm{Be},{ }^{14} \mathrm{C}$, and ${ }^{22} \mathrm{Na}$ are among the most important radionuclides because of their long half-life $\left(T_{1 / 2}\right)$ equivalent to 12.33 years for ${ }^{3} \mathrm{H}, 53$ days for ${ }^{7} \mathrm{Be}, 5,740$ years for ${ }^{14} \mathrm{C}$, and 2.6 years for ${ }^{22} \mathrm{Na}$, and they are of $\beta\left({ }^{3} \mathrm{H},{ }^{14} \mathrm{C}\right)$ and $\beta^{+}\left({ }^{22} \mathrm{Na}\right)$ radioactivity, and ${ }^{7} \mathrm{Be}$ is capturing electrons. These cosmogenic radionuclides in foods are without radiotoxic importance because they occur at an extremely small concentration in nature (Skwarzec 2012).

The decay series radionuclides are ${ }^{238} \mathrm{U}\left(T_{1 / 2}\right.$ of $4,500$ million years; $\alpha),{ }^{232} \mathrm{Th}\left(T_{1 / 2}\right.$ of 14,100 million years; $\alpha),{ }^{235} \mathrm{U}\left(T_{1 / 2}\right.$ of 704 million years; $\left.\alpha\right)$, and ${ }^{237} \mathrm{~Np}\left(T_{1 / 2}\right.$ of 2.14 million years; $\alpha$ ) series that during radioactive decay transform into many other radioactive elements, which can be, respectively, the emitters of $\alpha$ and $\beta^{-}$particles. And apart from ${ }^{238} \mathrm{U},{ }^{232} \mathrm{Th},{ }^{235} \mathrm{U}$, and ${ }^{237} \mathrm{~Np}$, the most risky in foods are ${ }^{234} \mathrm{U}\left(T_{1 / 2}\right.$ of 245,500 years; $\left.\alpha\right)$ and ${ }^{230} \mathrm{Th}\left(T_{1 / 2}\right.$ of 75,380 years; $\alpha$ ), while much weaker source of radiation dose are ${ }^{231} \mathrm{~Pa}\left(T_{1 / 2}\right.$ of 32,760 years; $\left.\alpha\right),{ }^{228} \mathrm{Th}\left(T_{1 / 2}\right.$ of 1.9 years; $\alpha),{ }^{229} \mathrm{Th}\left(T_{1 / 2}\right.$ of 734 years; $\left.\alpha\right),{ }^{227} \mathrm{Th}\left(T_{1 / 2}\right.$ of 18.7 days; $\alpha),{ }^{225}$ Ac $\left(T_{1 / 2}\right.$ of 10 days; $\left.\alpha\right),{ }^{223} \mathrm{U}\left(T_{1 / 2}\right.$ of 159,200 years; $\alpha$ ), and ${ }^{210}$ Po $\left(T_{1 / 2}\right.$ of 138 days; $\left.\alpha\right)$. Data on these types of element in mushrooms are almost nonexisting and the exception is $U$ for which many details can be found in the article by Gadd and Fomina (2011).

Since the 1940s, many radionuclides of anthropogenic origin have been released into the environment, and their sources relate to the testing of nuclear weapons, operation of nuclear power plants, radioactive waste disposal, and the manufacture of radioactive compounds. They are categorized into three groups: neutron activation products (1), fission products (2), and transuranic elements (3) (Skwarzec 2012). 
The activation of stable isotopes by neutron irradiation can produce various radionuclides, and their major source in nature is nuclear weapon testing, nuclear reprocessing, nuclear power plants, and nuclear research. By using modern radioanalytical methods, it is possible to detect the activation products such as ${ }^{22} \mathrm{Na},{ }^{51} \mathrm{Cr},{ }^{54} \mathrm{Mn},{ }^{65} \mathrm{Zn},{ }^{110 \mathrm{~m}} \mathrm{Ag}$, and ${ }^{124} \mathrm{Sb}$. The most important, due to its strong radioactivity and long-life, of the neutron activation (1) products are radionuclides such as ${ }^{54} \mathrm{Mn}\left(T_{1 / 2}\right.$ of 312 days; electrons capturing), ${ }^{55} \mathrm{Fe}$ ( $T_{1 / 2}$ of 2.737 years; electrons capturing), ${ }^{60} \mathrm{Co}\left(T_{1 / 2}\right.$ of 5.2714 years; $\left.\beta, \gamma\right),{ }^{6} \mathrm{Ni}\left(T_{1 / 2}\right.$ of 100.1 years; $\left.\beta^{-}\right),{ }^{64} \mathrm{Cu}\left(T_{1 / 2}\right.$ of 12.7 days; $\left.\beta^{+}\right),{ }^{110 \mathrm{~m}} \mathrm{Ag}\left(T_{1 / 2}\right.$ of 249.9 days; $\beta),{ }^{124} \mathrm{Sb}\left(T_{1 / 2}\right.$ of 60.2 days; $\beta$ ), and ${ }^{125} \mathrm{Sb}\left(T_{1 / 2}\right.$ of 2.76 years; $\beta$ ). Some of these radionuclides have been reported in mushrooms (Gentili et al. 1991).

The most important due to strong radioactivity and long-life, the radioactive fission products (2) formed in the explosion of nuclear bombs, both the uranium and plutonium bombs are radionuclides such as: ${ }^{90} \mathrm{Sr}\left(T_{1 / 2}\right.$ of 28.79 years; $\left.\beta^{-}\right),{ }^{131}$ I ( $\left(T_{1 / 2}\right.$ of 8.02 days; $\beta^{-}$and $\gamma$ ) and ${ }^{137} \mathrm{Cs}$ (long-lived, $T_{1 / 2}$ of 30.17 years. As indicated earlier, ${ }^{137} \mathrm{Cs}$ in mushrooms is well documented and data on both ${ }^{137} \mathrm{Cs}$ and ${ }^{134} \mathrm{Cs}$, which have different half life-time, help to study sources of pollution of mushrooms with those nuclides and also diffusion rates in soils (Mietelski et al. 2010).

For explosions in the atmosphere, the depositions of those radionuclides reaching the earth are $78 \%$ from stratospheric, $12 \%$ from local, and $10 \%$ from the tropospheric fallout (Skwarzec 2012). Radiocesium $\left({ }^{137} \mathrm{Cs}\right)$ is the most relevant nuclide from this source in mushrooms (see below). Also disasters of nuclear power plants apart from heavy local pollution are relevant regional sources of those radionuclides and largely of ${ }^{137} \mathrm{Cs}$ to soils, plants, mushrooms, and other biota in the food chain, e.g., the Chernobyl accident in 1986 (Dahlberg et al. 1997; Kostiainen 2007; Mietelski et al. 2010) and the Fukushima accident in 2011.

The transuranic elements (3) all are radioactive. Nuclear weapon tests and nuclear power production are major sources of transuranic elements to ambient environment ( $\mathrm{Np}, \mathrm{Pu}$, $\mathrm{Am}$, and $\mathrm{Cm}$ ).

From the point of view of strong radioactivity and longlife time, the most important among naturally occurring radionuclides mentioned are ${ }^{40} \mathrm{~K},{ }^{87} \mathrm{Rb}$, and some of the ${ }^{238} \mathrm{U},{ }^{232} \mathrm{Th},{ }^{235} \mathrm{U}$, and ${ }^{237} \mathrm{~Np}$ decay series. Radon from ${ }^{238} \mathrm{U}$ decay series that emanates from the ground into the atmosphere decays to ${ }^{210} \mathrm{~Pb}\left(T_{1 / 2} 22\right.$ years; $\left.\beta^{-}\right)$and ${ }^{210} \mathrm{Po}$ ( $T_{1 / 2} 138$ days; $\alpha$ ), and both return to the earth via wet deposition and on particles as dry deposition. The decay of ${ }^{238} \mathrm{U}$ also produces ${ }^{210} \mathrm{~Pb}$ and ${ }^{210} \mathrm{Po}$ in soil that are referred to as "supported" ${ }^{210} \mathrm{~Pb}$ and ${ }^{210} \mathrm{Po}$. Complementary sources of atmospheric ${ }^{210} \mathrm{Po}$ include dust storms, coal-burning, forest fires, and plant exudates (Skwarzec 2012). Both ${ }^{210} \mathrm{Po}$ and ${ }^{210} \mathrm{~Pb}$ are found in mushrooms (Mietelski et al. 2002; Skwarzec and Jakusik 2003; Baeza et al. 2004a).

Artificial radionuclides with ${ }^{137} \mathrm{Cs}$ as the major nuclide can be found in any wild-grown mushroom due to its deposition from the global radioactive fallout and persistency, while concentrations in mushrooms vary between species and regions and also on time scale. And one of the reasons is that with time passing, the radionuclides also undergo the process of infiltration (diffusion from surface down) into deeper soil layers. This process can be very slow. Mushrooms can capture ${ }^{137} \mathrm{Cs}$ from the surface of soils and decaying litter and from deeper soil layers, and this is related to fungal biology and placement of mycelium and depth and structure of soil layers. Fungi certainly are involved in biogeocycling of ${ }^{137} \mathrm{Cs}$ and by decaying fruit bodieslike in the case of other mineral elements, fungus can recycle ${ }^{137} \mathrm{Cs}$ from deeper soil layers back to the surface of forest carpet (Lepp et al. 1987; Smits and Hoffland 2009; Gryndler et al. 2012). More or less severe cases of mushroom contamination with artificial radionuclides have been reported at sites or regions of nuclear weapons testing and nuclear power plant failure (Taira et al. 2011).

\section{Potassium and radiopotassium}

The terrestrial origin of ${ }^{40} \mathrm{~K}\left(T_{1 / 2}\right.$ of $1.248 \times 10^{9}$ years; $\beta^{-}$, electrons capturing) and ${ }^{87} \mathrm{Rb}\left(T_{1 / 2}\right.$ of $4.92 \times 10^{10}$ years; emits $\beta^{-}$) is a significant source of radiation to humans while both occur at low concentrations in the rock crust $\left(<1 \mathrm{mBq} \mathrm{kg}^{-1}\right)$ (Skwarzec 2012). Mushrooms are rich in $\mathrm{K}$ and $\mathrm{Rb}$ (Tables 1 and 12). Typical contents of $\mathrm{K}$ and $\mathrm{Rb}$ in mushrooms are around 25,000 to 50,000 and $\sim 100$ to $300 \mathrm{mg} \mathrm{kg}^{-1} \mathrm{dm}$, respectively (Table 12). And fruit bodies are at least one order of magnitude richer in $\mathrm{K}$ and $\mathrm{Rb}$ and also in Cs compared to fungal mycelium (Vinichuk et al. 2011). The radionuclides ${ }^{40} \mathrm{~K}$ and ${ }^{87} \mathrm{Rb}$ are common constituents of mushrooms (Baeza et al. 2004a, b, 2005; Mietelski et al. 2010; and many others). The contents of ${ }^{40} \mathrm{~K}$ in mushrooms and other foods can be assessed from the concentrations of total $\mathrm{K}$ (by multiplying with 0.000117 ). Rubidium in nature consists of two isotopes, a stable ${ }^{85} \mathrm{Rb}$ $(72.2 \%)$ and radioactive ${ }^{87} \mathrm{Rb}(27.8 \%)$, and no data published are available on ${ }^{87} \mathrm{Rb}$ in mushrooms.

The activities of ${ }^{137} \mathrm{Cs}$ in fruit bodies were often compared with the natural content of ${ }^{40} \mathrm{~K}$. Potassium as an essential nutrient is "bio-adjustable" in that for a given species a certain concentration of $\mathrm{K}$ is favorable, and thus, the activity of ${ }^{40} \mathrm{~K}$ is relatively constant and this is typical for the given species and site. 
Table 12 Alkali metals and radionuclides (Na, K, Rb, Cs, ${ }^{137} \mathrm{Cs}$, and

${ }^{40} \mathrm{~K}$ ) in several species of mushrooms (data on $\mathrm{Na}, \mathrm{K}, \mathrm{Rb}$, and $\mathrm{Cs}$ are for caps of fruit bodies collected in $\sim 1986 \sim 2006$ and data on ${ }^{137} \mathrm{Cs}$ and
${ }^{40} \mathrm{~K}$ are for whole fruiting bodies) collected across of Poland (mean or median values and their range, respectively; adapted)

\begin{tabular}{|c|c|c|c|c|c|c|c|}
\hline Species & $\mathrm{Na}\left(\mathrm{mgkg}^{-1} \mathrm{dm}\right)$ & $\mathrm{K}\left(\mathrm{mgkg}^{-1} \mathrm{dm}\right)$ & $\mathrm{Rb}\left(\mathrm{mgkg}^{-1} \mathrm{dm}\right)$ & $\mathrm{Cs}\left(\mathrm{mgkg}^{-1} \mathrm{dm}\right)$ & ${ }^{137} \mathrm{Cs}\left(\mathrm{Bq} \mathrm{kg}^{-1} \mathrm{dm}\right)$ & ${ }^{40} \mathrm{~K}\left(\mathrm{~Bq} \mathrm{~kg}^{-1} \mathrm{dm}\right)$ & Ref. \\
\hline S. luteus & 55 & 39,000 & - & $20 \pm 5$ & $12,000^{\mathrm{a}}$ & $2,200^{\mathrm{a}} ;$ Suillus grevillei & A \\
\hline B. edulis & $170-200$ & $24,000-25,000$ & $330-370$ & $1.6-2.3$ & & & $\mathrm{~B}$ \\
\hline B. edulis & $100^{\mathrm{b}}$ & $26,000^{\mathrm{b}}$ & $650^{\mathrm{b}}$ & $8.7^{\mathrm{b}}$ & $5,100-13,000^{\mathrm{a}}$ & $970-2,100^{\mathrm{a}}$ & $\mathrm{B}$ \\
\hline L. amethystina & 360 & 51,000 & - & 0.79 & $5,600^{\mathrm{a}}$ & $2,100^{\mathrm{a}}$ & A \\
\hline T. equestre & 60 & 70,000 & - & $9.5 \pm 2.6$ & & & $\mathrm{C}$ \\
\hline T. equestre & $200-4,200$ & $32,000-83,000$ & $730-1,300$ & & $10,000^{\mathrm{a}}$ & $3,400^{\mathrm{a}} ;$ Tricholoma terrerum & $\mathrm{D}$ \\
\hline A. solidipes $^{\mathrm{c}}$ & 70 & 53,000 & & 0.95 & $315^{\mathrm{a}}$ & $1,800^{\mathrm{a}}$ & A \\
\hline L. scabrum & $270-380$ & $34,000-52,000$ & $240-330$ & $2.7-6.0$ & & & $\mathrm{E}$ \\
\hline L. scabrum & $290^{\mathrm{b}}$ & $35,000^{\mathrm{b}}$ & $320^{\mathrm{b}}$ & $7.2^{\mathrm{b}}$ & & & $\mathrm{E}$ \\
\hline M. procera & $20-290$ & $25,000-47,000$ & $18-230$ & $0.015-0.043$ & $1,100^{\mathrm{a}}$ & $1,500^{\mathrm{a}}$ & $\mathrm{F}$ \\
\hline P. involutus & $90-520$ & $30,000-63,000$ & $130-670$ & $0.8-7.8$ & & & $\mathrm{~F}$ \\
\hline P. involutus & $180^{\mathrm{b}}$ & 30,000 & $410^{\mathrm{b}}$ & $20^{\mathrm{b}}$ & $2,500-10,000^{\mathrm{a}}$ & $2,000-2,300^{\mathrm{a}}$ & $\mathrm{F}$ \\
\hline A. muscaria & $30-37$ & $37,000-45,000$ & $58-300$ & $0.063-0.83$ & & & $\mathrm{~F}$ \\
\hline
\end{tabular}

A (Falandysz et al. 2001a, b; Mietelski et al. 2010); B (Falandysz et al. 2008a); C (Falandysz et al. 2001a, b; J.F., unpublished); D (Mietelski et al. 2010; J.F., unpublished); E (Falandysz et al. 2007e); F (Falandysz et al. 2008b; Mietelski et al. 2010; Jarzyńska et al. 2011; Kojta et al. 2011; Drewnowska et al. 2012c; Gucia et al. 2012a, b); G (Falandysz et al. 2007d; Brzostowski et al. 2009, 2011a, b; Mietelski et al. 2010); H (Falandysz et al. 2007f)

a A "hot spot" site near the city of Opole in south-western Poland in 2006-2007

${ }^{\mathrm{b}}$ Data for specimens collected from Kłodzka Dale in Sudety Mountains in south-western Poland

${ }^{\mathrm{c}}$ Earlier called also as A. mellea and A. ostoyae

\section{Cesium and radiocesium}

Radiocesium $\left({ }^{137} \mathrm{Cs}\right)$ is the nuclide on which public interest is mainly focused and it is widely studied in wild-grown mushrooms (Kirchner and Daillant 1998; Baeza et al. 2004b, 2005; Mietelski et al. 2002, 2010; Kostiainen 2007; Taira et al. 2011; Castro et al. 2012; and many others). The ${ }^{137} \mathrm{Cs}$ and other nuclides deposited from fallout are further absorbed by fungi from soils (decaying litter and organic and inorganic soil layers-elements diffused into soil solution), and there is no discrimination between decaying and stable isotopes of a particular element undergoing uptake by mycelia. Hence, the efficiency of radionuclides bioaccumulation in mushrooms as a phenomenon does not vary from that of metals at sites polluted due to depositions from smelters: that which is easily accessible is readily accumulated and no extra energy is lost by the organism. A good example to explain this are metals (e.g., $\mathrm{Ni}$ and Cd) found at elevated concentrations in mushrooms collected at sites exposed to metal fumes deposited from metal smelters (Barcan et al. 1998; Collin-Hansen et al. 2002). "Efficient" bioaccumulation of ${ }^{137} \mathrm{Cs}$ by fungi is a feature related to mushroom species which depends on the "need" for stable Cs, which is an abundant element in mushrooms (Table 12) and on the efficiency of radionuclide diffusion into soil solution (stable Cs can be supplied from other pools which can be less accessible and to deficiency of ${ }^{137} \mathrm{Cs}$ in solution).

A large-scale remediation of soils polluted with radionuclides and especially with ${ }^{137} \mathrm{Cs}$ is out of real possibilities and polluted sites become abandoned grounds for years. Rosén et al. (2011) suggested that a single $(100 \mathrm{kgK} / \mathrm{ha})$ treatment of forest soil with potassium $(\mathrm{KCl})$ fertilizer in 1992 could have a long-term (even 17 years after application) impact on bioaccumulation of ${ }^{137} \mathrm{Cs}$ by Cortinarius semisanguineus, Lactarius rufus, Cortinarius caperatus, and S. variegatus mushrooms-radioactivity is reduced from 21 to $58 \%$. An attempt to use stable Cs salts to reduce uptake of ${ }^{137} \mathrm{Cs}$ by forest mushrooms and berries has not been reported.

Mushroom contents of stable Cs vary between its morphological parts, and in caps, it is around twice more abundant in Cs than in stipe. High geographical (spatial) variations in the contents of Cs in mushrooms have been noted. For example, the mycorrhizal species such as B. edulis and L. scabrum with 1.6 to $8.7 \mathrm{mg} \mathrm{Cs} \mathrm{kg}^{-1} \mathrm{dm}$ (median values) in caps are richer in this element compared to mycorrhizals, such as A. muscaria with 0.063 to $0.83 \mathrm{mgkg}^{-1} \mathrm{dm}$ and up to $20 \mathrm{mg} \mathrm{kg}^{-1} \mathrm{dm}$ in $P$. involutus (Falandysz et al. 2007c, d, e, 2008a). The saprophytic $M$. procera contained stable $\mathrm{Cs}$ in caps at 0.015 to $0.043 \mathrm{mgkg}^{-1} \mathrm{dm}$ (median values) (Falandysz et al. 2008b), and this is low compared to mycorrhizal mushrooms 
mentioned. Hence, there is no doubt that ${ }^{137} \mathrm{Cs}$ can be more efficiently sequestered in flesh by many mycorrhizal mushrooms than saprophytic mushrooms (Rühm et al. 1997).

As mentioned, the largest radioactivity from artificial radionuclides in mushrooms usually comes from ${ }^{137} \mathrm{Cs}$, but this can differ regionally. In a study in France, the contribution to the gamma-radioactivity from ${ }^{134} \mathrm{Cs},{ }^{137} \mathrm{Cs},{ }^{210} \mathrm{~Pb}$, and ${ }^{226} \mathrm{Ra}$ for the majority of mushrooms was highest for ${ }^{210} \mathrm{~Pb}$. Mushrooms there contained ${ }^{210} \mathrm{~Pb}$ at $<1.76$ to $36.5 \mathrm{~Bq} \mathrm{~kg}^{-1} \mathrm{dm}$ and for ${ }^{226} \mathrm{Ra}$ was an order of magnitude less. And in species that are eaten less frequently and at lower rate, the radioactivity from ${ }^{137} \mathrm{Cs}$ was greatest - up to 2,860 $\mathrm{Bq} \mathrm{kg}^{-1} \mathrm{dm}$ (Kirchner and Daillant 1998).

In studies in Finland, the activity concentrations of ${ }^{137} \mathrm{Cs}$ in 600 samples of mushrooms collected in 2000-2005 were between 10 and 3,000 $\mathrm{Bqkg}^{-1}$ (low in Leccinum spp., Gyromitra spp., and Scutiger ovinus; medium in B. edulis, C. cibarius, and Russula sp.; and high in, e.g., Cantharellus tubaeformis, C. cornucopioides, Lactarius spp., Hydnum spp., S. variegates, and Cortinarius caperatus), and no significant reduction in activity could be noted over that time (Kostiainen 2007). In addition, after comparison of data given for radioactivity in the same species but collected at the same site in 1986-1988, no decrease was found from 1986 to 2005 . For B. edulis, whose mycelium lives relatively deeper in soil layer, the radioactivity increased as the post-Chernobyl ${ }^{137} \mathrm{Cs}$ infiltrated deeper into the soil horizon (Kostiainen 2007). Later, a similar result was noted for $B$. edulis elsewhere (Mietelski et al. 2010).

\section{Other radionuclides}

Compared to ${ }^{137} \mathrm{Cs}$ and ${ }^{40} \mathrm{~K}$, less data are published on other radionuclides in mushrooms both natural and artificial. Other radionuclides studied in mushrooms include ${ }^{210} \mathrm{Po}$, ${ }^{234,238} \mathrm{U},{ }^{228,230,232} \mathrm{Th},{ }^{90} \mathrm{Sr}{ }^{239+240} \mathrm{Pu},{ }^{238} \mathrm{Pu}{ }^{241} \mathrm{Am},{ }^{134} \mathrm{Cs}$, ${ }^{85} \mathrm{Sr},{ }^{60} \mathrm{Co}$ and ${ }^{226} \mathrm{Ra}$ (Kirchner and Daillant 1998; Mietelski et al. 2002; Skwarzec and Jakusik 2003; Baeza et al. 2004a; Szántó et al. 2007; Vaartamaa et al. 2009). In view of the current knowledge, the amounts of these radionuclides reported for edible wild-grown mushrooms that emerged at areas not close to sites of nuclear tests and accidents, as well as for cultivated species and mushrooms, are below accepted doses for internal exposure.

\section{Technical problems related to trace minerals in mushrooms}

The truth is that accurate and precise analytical methods are needed when studying any mineral constituent in any abiotic or biotic matrices. In several articles (old and new) on trace minerals in mushrooms, unreliable data were published on elements ( $\mathrm{Se}, \mathrm{Hg}, \mathrm{Fe}, \mathrm{Co}, \mathrm{Cr}, \mathrm{V}, \mathrm{Ni}, \mathrm{Rb}, \mathrm{Ba}, \mathrm{Cs}, \mathrm{Sr}, \mathrm{U}, \mathrm{Zr}$ and on the rare earth elements such as $\mathrm{Ga}, \mathrm{Nb}, \mathrm{Ce}, \mathrm{Th}, \mathrm{Nd}$, and also $\mathrm{Li}, \mathrm{Cd}$, and $\mathrm{Pb}$ ) sequestered in fruit bodies. Regrettably, many of such "dubious" data were published in journals that specialized in trace element research. A clear documentation of all such cases will need further investigations, and some aspects of such cases are discussed in detail elsewhere (Falandysz and Lipka 2006; Borovička and Řanda 2007; Falandysz 2008, 2012, 2013; Falandysz et al. 2012a, 2013; Borovička et al. 2011; Jarzyńska and Falandysz 2011a, b; Jarzyńska et al. 2012a). The biased analytical data published give a false picture of the composition and nutritional value of mushrooms with respect to minerals. Certainly, if a well-studied species is not classified as a hyperaccumulator of given mineral elements and is not collected from a polluted or geoanomalous site, a high load of element in its fruit body (example is $\mathrm{Se}, \mathrm{Hg}, \mathrm{Fe}, \mathrm{Cr}, \mathrm{Co}$, $\mathrm{Li}, \mathrm{Cd}, \mathrm{V}, \mathrm{Ni}, \mathrm{Ba}, \mathrm{Sr}, \mathrm{Zr}$ ) is not expected. When species of mushroom is without earlier published data on its mineral composition, the proper choice of analytical method and basic rules of chemical analysis must be applied.

A good example of this kind of problems is the case of Se (total Se) in mushrooms. As discussed earlier (see Se section), mushrooms have high variability in their contents of Se. Some mushrooms are specifically rich in this element and a credible range for all species studied until now is from $\sim 0.01$ to $370 \mathrm{mgkg}^{-1} \mathrm{dm}$ (some recent and totally biased data showed even around 190 to $420 \mathrm{mg} \mathrm{Se} \mathrm{kg}{ }^{-1} \mathrm{dm}$ as typical values for certain species) (Falandysz 2013). Selenium for many reasons remains a challenge to analysts, agronomists, nutritionists, physicians, and the public. As mentioned, Se has a high biological potential and its content in foods is usually small, and also small Se doses are required in human nutrition usually between 1 and $3.3 \mu \mathrm{g}$ $\mathrm{kg}^{-1}$ bm daily.

Several of the sample preparation methods and instrumental measurement techniques have been applied for the examination of Se in mushrooms. These instrumental techniques include UV-VIS spectrophotometry, gas chromatography, flame atomic-absorption spectroscopy (AAS), hydride generation-atomic absorption spectroscopy (HGAAS), hydride generation graphite furnace-atomic absorption spectroscopy (HG-GF-AAS), inductively coupled plasma atomic emission spectroscopy (ICP-AES), inductively coupled plasma mass spectrometry, fluorimetry (FLU), and neutron activation analysis (INAA) (Falandysz 2013). To determine total Se content of mushroom after wet digestion (with oxidizing acids), the Se contained in analyte needs to be separated (to enhance sensitivity and remove interferences) before aspiration to flame AAS. This is offered by HGAAS and HG-GF-AAS but not by ordinary F-AAS because it lacks sensitivity for Se (Figs. 2 and 3). Also in the case of 


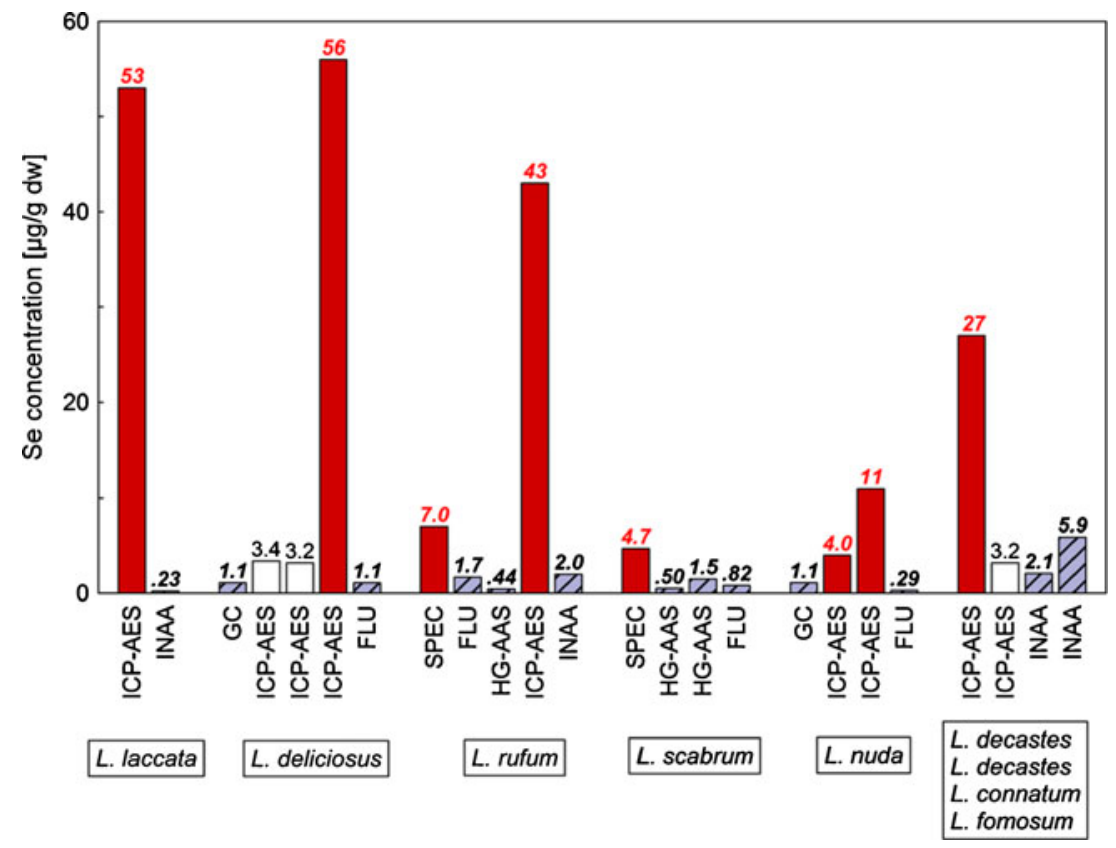

Fig. 2 Selenium in mushrooms such as Laccaria laccata, Lactarius deliciosus, Leccinum rufum, Leccinum scabrum, Lepista nuda, Lyophylum decastes, Lyophylum connatum, and Lyophylum fomosum by several authors and techniques (mean values - data adapted from the references cited, respectively; color figure available online) [dark shadowed bars (in red online) relate to suspicious results because of highly

ICP-AES, the Se contained in the wet digested mushroom sample has to be separated (as hydride) before aspiration of digest to plasma. Determination of Se by ICP-AES without its pre-separation suffers due to common, nonspectral interferences, because of the formation of carbonyl ions that excessive values reported due to selection of improper method of determination; the empty bars (in white online) relate to methods of measurement which can give incorrect result due to low sensitivity or nonspecific interferences that are difficult to control; and the light shadowed bars with askew lines (shadowed in bluish online) are data that appear to be acceptable and by valid methods] (from Falandysz 2013)
Fig. 3 Selenium in mushrooms such as Cantharellus cibarius, Chroogompus rutilus, Clitocybe odora, Collybia meculata, and Coprinus comatus by several authors and techniques (mean values-adapted; color figure available online) (from Falandysz 2013)

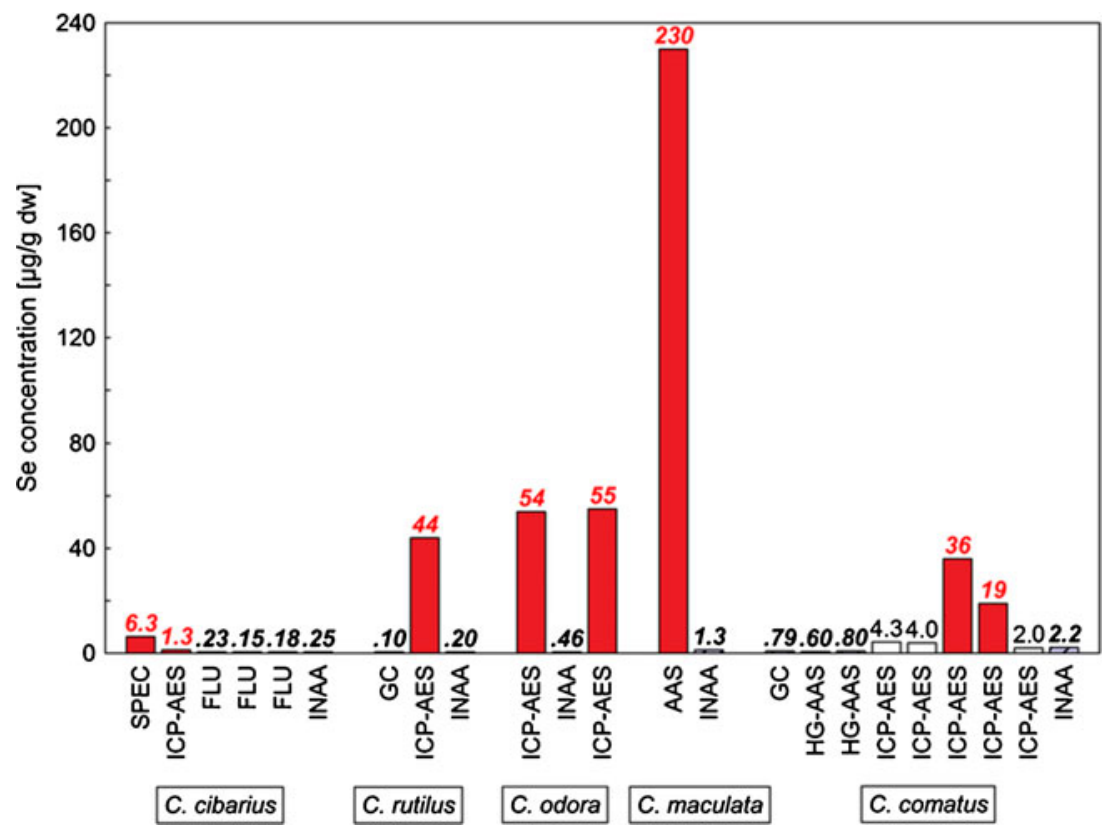


Acknowledgments A generous support from Dr. Chidi I. Nnorom is acknowledged. The work on this paper was supported in part by grant no DS 530-8131-0197-13 from Poland and to Jan Borovička by the project 504/11/0484 (Czech Science Foundation); institutional support was provided by Long-term Development Projects RVO61389005 and RVO67985831.

Open Access This article is distributed under the terms of the Creative Commons Attribution License which permits any use, distribution, and reproduction in any medium, provided the original author(s) and the source are credited.

\section{References}

Agerer R, Christian J, Mayr C, Hobbie E (2012) Isotopic signatures and trophic status of Ramaria. Mycol Prog 11:47-59

Alonso J, Salgado M, Gariciá M, Melgar M (2000) Accumulation of mercury in edible macrofungi: influence of some factors. Arch Environ Contam Toxicol 38:158-162

Aloupi M, Koutrotsios G, Koulousaris M, Kalogeropoulos N (2011) Trace metal contents in wild edible mushrooms growing on serpentine and volcanic soils on the island of Lesvos, Greece. Ecotoxicol Environ Saf 78:184-194. doi:10.1016/j.ecoenv.2011.11.018

Amundson R, Richter DD, Humphreys GS, Jobbágy EG, Gaillardet J (2007) Coupling between biota and Earth materials in the critical zone. Elements 3:327-332. doi:10.2113/gselements.3.5.327

Andersson HC, Gry J (2004) Phenylhydrazines in the cultivated mushroom (Agaricus bisporus) - occurrence, biological properties, risk assessment and recommendations. Temanord 2004:558

Antibus RK, Bower D, Dighton J (1997) Root surface phosphatase activities and uptake of ${ }^{32} \mathrm{P}$ labelled inositol phosphate in fieldcollected gray birch and red maple roots. Mycorrhiza 7:39-46

Assunção LS, de Luz JM, de Cássia Soares da Silva, Fontes V, Soares B, Dantas V (2012) Enrichment of mushrooms: an interesting strategy for the acquisition of lithium. Food Chem 134:1123-1127

Baeza A, Guillén J, Mietelski JW (2004a) Uptake of alpha and beta emitters by mushrooms collected and cultured in Spain. J Radioanal Nucl Chem 261:375-380

Baeza A, Hernández S, Guillén J, Moreno G, Manjóon JL, Pascuala R (2004b) Radiocaesium and natural gamma emitters in mushrooms collected in Spain. Sci Total Environ 408:84-91

Baeza A, Guillén J, Bernedo JM (2005) Soil-fungi transfer coefficients: importance of the location of mycelium in soil and of the differential availability of radionuclides in soil fractions. J Environ Radioact 81:89-106

Bakken LR, Olsen RA (1990) Accumulation of radiocaesium in fungi. Can J Microbiol 36:70-710

Baldrian P (2008) Chapter 2: enzymes of saprotrophic basidiomycetes. In: Boddy L, Frankland JC, van West P (eds) Ecology of saprotrophic Basidiomycetes. British Mycological Society Symposia Series, Vol. 28. Elsevier, Amsterdam, pp 19-41

Barcan VS, Kovnatsky EF, Smetannikova MS (1998) Absorption of heavy metals in wild berries and edible mushrooms in an area affected by smelter emissions. Water Air Soil Pollut 103:173-195

Bargagli R, Baldi F (1984) Mercury and methylmercury in higher fungi and their relation with the substrata in a cinnabar mining area. Chemosphere 13:1059-1071

Bhatia P, Prakash R, Cameotra SS, Aureli F, Cubadda F, D'Amato M, Nagaraja TP (2011) Fortification of edible mushrooms with selenium using naturally enriched substrates. 4th International IUPAC Symposium for Trace Elements in Foods (TEF-4). King's College, Aberdeen, Scotland, 19-22 June 2011. P/19/0040
Blackwell M (2011) The fungi: 1, 2, 3 ... 5.1 million species? Am J Bot 98:426-438

Blaudez D, Chalot M (2011) Characterization of the ER-located zinc transporter ZnT1 and identification of a vesicular zinc storage compartment in Hebeloma cylindrosporum. Fungal Genet Biol 48:96-503

Borovička J (2004) A new locality of Sarcosphaera coronaria [In Czech]. Mykol Sborn 81:97-100

Borovička J, Randa Z (2007) Distribution of iron, cobalt, zinc and selenium in macrofungi. Mycol Prog 6:249-259

Borovička J, Řanda Z, Jelínek E (2005) Gold content of ectomycorrhizal and saprobic macrofungi from non-auriferous and unpolluted areas. Mycol Res 109:951-955

Borovička J, Řanda Z, Jelínek E (2006) Antimony content of macrofungi from clean and polluted areas. Chemosphere 64:1837-1844

Borovička J, Řanda Z, Jelínek E, Kotrba P, Dunn CE (2007) Hyperaccumulation of silver by Amanita strobiliformis and related species of the section Lepidella. Mycol Res 111:1339-1344

Borovička J, Dunn CE, Gryndler M, Mihaljevič M, Jelínek E, Rohovec J, Rohošková M, Řanda Z (2010a) Bioaccumulation of gold in macrofungi and ectomycorrhizae from the vicinity of the Mokrsko gold deposit, Czech Republic. Soil Biol Biochem 42:83-91

Borovička J, Kotrba P, Gryndler M, Mihaljevič M, Řanda Z, Rohovec J, Cajthaml T, Stijve T, Dunn CE (2010b) Bioaccumulation of silver in ectomycorrhizal and saprobic macrofungi from pristine and polluted areas. Sci Total Environ 408:2733-2744

Borovička J, Kubrová J, Rohovec J, Řanda Z, Dunn CE (2011) Uranium, thorium and rare earth elements in macrofungi: what are the genuine concentrations? Biometals 24:837-845

Boyd RS (2007) The defense hypothesis of elemental hyperaccumulation: status, challenges and new directions. Plant Soil 293:153-176

Brzostowski A, Bielawski L, Orlikowska A, Plichta S, Falandysz J (2009) Instrumental analysis of metals profile in Poison Pax (Paxillus involutus) collected at two sites in Bory Tucholskie. Chem Anal (Warsaw) 54:907-919

Brzostowski A, Falandysz J, Jarzyńska G, Zhang D (2011a) Bioconcentration potential of metallic elements by Poison Pax (Paxillus involutus) mushroom. J Environ Sci Health A 46:378-393

Brzostowski A, Jarzyńska G, Kojta AK, Wydmańska D, Falandysz J (2011b) Variations in metal levels accumulated in Poison Pax (Paxillus involutus) mushroom collected at one site over four years. J Environ Sci Health A 46:581-588

Byrne AR, Ravnik V, Kosta L (1976) Trace element concentrations in higher fungi. Sci Total Environ 6:65-78

Byrne AR, Šlejkovec Z, Stijve T, Fay L, Gössler W, Gailer J, Irgolic KJ (1995) Arsenobetaine and other arsenic species in mushrooms. Appl Organomet Chem 9:305-313

Campos JA, Tejera NA, Sánchéz CJ (2009) Substrate role in the accumulation of heavy metals in sporocarps of wild fungi. Biometals 22:835-841

Castro LP, Maihara VA, Silva PSC, Figueira RCI (2012) Artificial and natural radioactivity in edible mushrooms from Sao Paulo. Brazil J Environ Radioact 113:150-154

Cen F, Chen L, Hu Y, Xu H (2012) Chelator induced bioextraction of heavy metals from artificially contaminated soil by mushroom (Coprinus comatus). Chem Ecol 28:267-280

Chalot M, Brun A (1998) Physiology of organic nitrogen acquisition by ectomycorrhizal fungi and ectomycorrhizas. FEMS Microbiol Rev 22:21-44

Chojnacka A, Jarzyńska G, Drewnowska M, Nnorom IC, Falandysz J (2012) Yellow-cracking Boletes (Xerocomus subtomentosus) mushrooms: content and potential to sequestrate mercury. J Environ Sci Health A 47:2094-2100

Christ S, Wubet T, Theuerl T, Herold N, Buscot F (2011) Fungal communities in bulk soil and stone compartments of different 
forest and soil types as revealed by a barcoding ITS rDNA and a functional laccase encoding gene marker. Soil Biol Biochem 43:1292-1299

Chudzyński K, Falandysz J (2008) Multivariate analysis of elements content of Larch Bolete (Suillus grevillei) mushroom. Chemosphere 73:1230-1239

Chudzyński K, Bielawski L, Falandysz J (2009) Mercury bioconcentration potential of Larch Bolete, Suillus grevillei, mushroom. Bull Environ Contam Toxicol 83:275-279

Chudzyński K, Jarzyńska G, Stefańska A, Falandysz J (2011) Mercury content and bio-concentration potential of Slippery Jack, Suillus luteus, mushroom. Food Chem 125:986-990

Cocchi L, Vescovi L, Petrini L, Petrini O (2006) Heavy metals in edible mushrooms in Italy. Food Chem 98:277-284

Collin-Hansen C, Yittri KE, Andersen RA, Berthelse BO, Steinnes E (2002) Mushrooms from two metal-contaminated areas in Norway: occurrence of metals and metallothionein-like proteins. Geochem Explor Environ Anal 2:2074-2076

Collin-Hansen C, Pedersen SA, Andersen RA, Steinnes E (2003) First report of phytochelatins in a mushroom: induction of phytochelatins by metal exposure in Boletus edulis. Mycologia 99:161-174

Collin-Hansen C, Andersen RA, Steinnes E (2005) Damage to DNA and lipids in Boletus edulis exposed to heavy metals. Mycol Res 109:1386-1396

Costa-Silva F, Marques G, Matos CC, Barros AIRNA, Nunes FM (2011) Selenium contents of Portuguese commercial and wild edible mushrooms. Food Chem 126:91-96

Courbot M, Diez L, Ruotolo R, Chalot M, Leroy P (2004) Cadmiumresponsive thiols in the ectomycorrhizal fungus Paxillus involutus. Appl Environ Microbiol 70:7413-7417

Crane S, Dighton J, Barkay T (2010) Growth responses to and accumulation of mercury by ectomycorrhizal fungi. Fungal Biol 114:873-880

Dahlberg A, Kanikolova I, Johanson K-J (1997) Intraspecific variation in ${ }^{137} \mathrm{Cs}$ activity concentration in sporocarps of Suillus variegatus in seven Swedish populations. Mycol Res 101:545-551

Drbal K, Kalač P, Šeflová A, Šefl J (1975a) Iron and manganese content in some edible macrofungi [In Czech]. Czech Mycol 29:110-114

Drbal K, Kalač P, Šeflová A, Šefl J (1975b) Copper content in some edible macrofungi [In Czech]. Czech Mycol 29:184-186

Drewnowska M, Jarzyńska G, Kojta AK, Falandysz J (2012a) Mercury in European Blusher, Amanita rubescens, mushroom and soil. Bioconcentration potential and intake assessment. J Environ Sci Health B 47:466-474

Drewnowska M, Jarzyńska G, Sapór A, Nnorom IC, Sajwan KS, Falandysz J (2012b) Mercury in Russula mushrooms: bioconcentration by yellow-ocher Brittle Gills Russula ochroleuca. J Environ Sci Health A 47:1577-1591

Drewnowska M, Lipka K, Jarzyńska G, Danisiweicz-Czupryńska D, Falandysz J (2012c) Investigation on metallic elements of Fly Agaric, Amanita muscaria, fungus and the forest soils from the Mazurian Lakes District of Poland. Fresenius Environ Bull 21. doi:10.3291/F-2012-571pj2013

Estrada AER, Lee H-J, Beelman RB, Jimenez-Gasco M, Royse DJ (2009) Enhancement of the antioxidants ergothineine and selenium in Pleurotus eryngi var. eryngi basidiomata through cultural practice. World J Microbiol Biotechnol 25:1597-1607

Falandysz J (2002) Mercury in mushrooms and soil of the Tarnobrzeska Plain, southeastern Poland. J Environ Sci Health Part A 37:343-352

Falandysz J (2008) Selenium in edible mushrooms. J Environ Sci Health C 26:256-299

Falandysz J (2010) Mercury in certain mushrooms species in Poland. In: Rai M, Kōvics G (eds) Progress in mycology. Scientific, Jodhpur, pp 349-383
Falandysz J (2012) Comments on "Determination of mercury, cadmium, lead, zinc, selenium and iron by ICP-OES in mushroom samples from around thermal power plant in Muğla, Turkey". doi. 10.1007/s00128-011-0357-1. Bull Environ Contam Toxicol 88:651-653. doi:10.1007/s00128-012-0566-2

Falandysz J (2013) Review: On published data and methods for selenium in mushrooms. Food Chem. doi:10.1016/j.foodchem.2012.10.046

Falandysz J, Bielawski L (2001) Mercury content of wild edible mushrooms collected near the town of Augustów. Pol J Environ Stud 10:67-71

Falandysz J, Bielawski L (2007) Mercury and its bioconcentration factors in Brown Birch Scaber Stalk (Leccinum scabrum) from various sites in Poland. Food Chem 105:635-640

Falandysz J, Brzostowski A (2007) Mercury and its bioconcentration factors in Poison Pax (Paxillus involutus) from various sites in Poland. J Environ Sci Health A 42:1095-1100

Falandysz J, Chwir A (1997) The concentrations and bioconcentration factors of mercury in mushrooms from Mierzeja Wiślana sandbar, Northern Poland. Sci Total Environ 203:221-228

Falandysz J, Danisiewicz D (1995) Bioconcentration factors (BCF) of silver in wild Agaricus campestris. Bull Environ Contam Toxicol $55: 122-129$

Falandysz J, Gucia M (2008) Bioconcentration factors of mercury by parasol mushroom (Macrolepiota procera). Environ Geochem Health 30:121-125

Falandysz J, Lipka K (2006) Selen w grzybach [In Polish]. Roczn Państw Zakł Hig 52:217-233

Falandysz J, Bona H, Danisiewicz D (1994a) Silver content of wildgrown mushrooms from northern Poland. Z Lebensm Unters Forsch 199:222-224

Falandysz J, Bona H, Danisiewicz D (1994b) Silver uptake by Agaricus bisporus from an artificially enriched substrate. Z Lebensm Unters Forsch 199:225-228

Falandysz J, Gucia M, Frankowska A, Kawano M, Skwarzec B (2001a) Total mercury in wild mushrooms and underlying soil substrate from the city of Umeå and its surroundings, Sweden. Bull Environ Contam Toxicol 67:767-770

Falandysz J, Szymczyk K, Ichihashi H, Bielawski L, Gucia M, Frankowska A, Yamasaki S (2001) ICP/MS and ICP/AES elemental analysis (38 elements) of edible wild mushrooms growing in Poland. Food Addit Contam 18:503-513

Falandysz J, Bielawski L, Kannan K, Gucia M, Lipka K, Brzostowski A (2002a) Mercury in wild mushrooms and underlying soil substrate from the great lakes land in Poland. J Environ Monit 4:473-476

Falandysz J, Bielawski L, Kawano M, Brzostowski A, Chudzyński K (2002b) Mercury in mushrooms and soil from the Wieluńska Upland in south-central Poland. J Environ Sci Health A 37:1409-1420

Falandysz J, Gucia M, Skwarzec B, Frankowska A, Klawikowska K (2002c) Total mercury in mushrooms and underlying soil from the Borecka Forest, Northeastern Poland. Arch Environ Contam Toxicol 42:145-154

Falandysz J, Lipka K, Gucia M, Kawano M, Strumnik K, Kannan K (2002d) Accumulation factors of mercury in mushrooms from Zaborski Landscape Park, Poland. Environ Int 28:421-427

Falandysz J, Brzostowski A, Kawano M, Kannan K, Puzyn T, Lipka K (2003a) Concentrations of mercury in wild growing higher fungi and underlying substrate near Lake Wdzydze, Poland. Water Air Soil Pollut 148:127-137

Falandysz J, Gucia M, Brzostowski A, Kawano M, Bielawski L, Frankowska A, Wyrzykowska B (2003b) Content and bioconcentration of mercury in mushrooms from northern Poland. Food Addit Contam 20:247-253

Falandysz J, Lipka K, Kawano M, Brzostowski A, Dadej M, Jędrusiak A, Puzyn T (2003c) Mercury content and its bioconcentration factors at Łukta and Morag, Northeastern Poland. J Agric Food Chem 51:2835-2836 
Falandysz J, Kawano M, Świeczkowski A, Brzostowski A, Dadej M (2003d) Total mercury in wild-grown higher mushrooms and underlying soil from Wdzydze Landscape Park, Northern Poland. Food Chem 81:21-26

Falandysz J, Jędrusiak A, Lipka K, Kannan K, Kawano M, Gucia M, Brzostowski A, Dadej M (2004) Mercury in wild mushrooms and underlying soil substrate from Koszalin, North-central Poland. Chemosphere 54:461-466

Falandysz J, Frankowska A, Mazur A (2007a) Mercury and its bioconcentration factors in King Bolete (Boletus edulis) Bull. Fr. J Environ Sci Health A 42:2089-2095

Falandysz J, Gucia M, Mazur A (2007b) Content and bioconcentration factors of mercury by Parasol Mushroom Macrolepiota procera. J Environ Sci Health A 42:735-740

Falandysz J, Kunito T, Kubota R, Brzostowski A, Mazur A, Falandysz JJ, Tanabe S (2007c) Selected elements of Poison Pax Paxillus involutus. J Environ Sci Health A 42:1161-1168

Falandysz J, Kunito T, Kubota R, Lipka K, Mazur A, Falandysz JJ, Tanabe S (2007d) Selected elements in Fly Agaric Amanita muscaria. J Environ Sci Health A 42:1615-1623

Falandysz J, Kunito T, Kubota R, Bielawski MA, Falandysz JJ, Tanabe S (2007e) Selected elements in Brown Birch Scaber Stalk Leccinum scabrum. J Environ Sci Health A 42:2081-2088

Falandysz J, Lipka K, Mazur A (2007f) Mercury and its bioconcentration factors in Fly Agaric (Amanita muscaria) from spatially distant sites in Poland. J Environ Sci Health A 42:1625-1630

Falandysz J, Kunito T, Kubota R, Bielawski L, Frankowska A, Falandysz JJ, Tanabe S (2008a) Multivariate characterization of elements accumulated in King Bolete Boletus edulis mushroom at lowland and high mountain regions. J Environ Sci Health A 43:1692-1699

Falandysz J, KunitoT KR, Gucia M, Mazur A, Falandysz JJ, Tanabe S (2008b) Some mineral constituents of Parasol Mushroom Macrolepiota procera. J Environ Sci Health B 43:187-192

Falandysz J, Frankowska A, Jarzyńska G, Dryżałowska A, Kojta AK, Zhang D (2011) Survey on composition and bioconcentration potential of 12 metallic elements in King Bolete (Boletus edulis) mushroom that emerged at 11 spatially distant sites. J Environ Sci Health B 46:231-246

Falandysz J, Chudzyński K, Kojta AK, Jarzyńska G, Drewnowska M (2012a) Comparison of two acid extraction methods for determination of minerals in soils beneath to Larch Bolete (Suillus grevillei) and aimed to estimate minerals sequestration potential in fruiting bodies. J Environ Sci Health A 47:1607-1613

Falandysz J, Drewnowska M, Jarzyńska G, Zhang D, Zhang Y, Wang J (2012b) Mineral constituents in Common Chanterelles and soils collected from a high mountain and lowland sites in Poland. J Mt Sci 9:697-705

Falandysz J, Kojta AK, Jarzyńska G, Drewnowska A, Dryżałowska A, Wydmańska D, Kowalewska I, Wacko A, Szlosowska M, Kannan K, Szefer P (2012c) Mercury in Bay Bolete Xerocomus badius: bioconcentration by fungus and assessment of element intake by humans eating fruiting bodies. Food Addit Contam A 29:951-961

Falandysz J, Kowalewska I, Nnorom IC, Drewnowska M, Jarzyńska G (2012d) Mercury in Red Aspen Boletes (Leccinum aurantiacum) mushrooms and the soils. J Environ Sci Health A 47:1695-1700

Falandysz J, Nnorom IC, Jarzyńska G, Romińska D, Damps K (2012e) A study of mercury bio-concentration by Puffballs (Lycoperdon perlatum) and evaluation of dietary intake risks. Bull Environ Contam Toxicol 89:759-763

Falandysz J, Widzicka E, Kojta AK, Jarzyńska G, Drewnowska M, Danisiewicz-Czupryńska D, Dryżałowska A, Lenz E, Nnorom IC (2012f) Mercury in Common Chanterelles mushrooms: Cantharellus spp. update. Food Chem 133:842-850

Falandysz J, Mazur A, Drewnowska M, Kojta AK, Jarzyńska G, Dryżałowska A, Nnorom IC (2013) Mercury in fruiting bodies of dark honey fungus (Armillaria solidipes) and beneath substratum soils collected from spatially distant areas. J Sci Food Agric 92. doi:10.1002/jsfa.5807

Fischer RG, Rapsomanikis S, Andreae MO, Baldini F (1995) Bioaccumulation of methylmercury and transformation of inorganic mercury by macrofungi. Environ Sci Technol 29:993-999

Fomina M, Alexander IJ, Colpaert JV, Gadd GM (2006) Solubilization of toxic metal minerals and metal tolerance of mycorrhizal fungi. Soil Biol Biochem 37:851-866

Fomina M, Charnock JM, Hillier S, Alvarez R, Gadd GM (2007) Fungal transformations of uranium oxides. Environ Microbiol 9:1696-1710

Frankowska A, Ziółkowska J, Bielawski L, Falandysz J (2010) Profile and bioconcentration of minerals by King Bolete (Boletes edulis) from the Płocka Dale in Poland. Food Addit Contam B 3:1-6

Friese W (1929) Mineral composition of macrofungi. Z Unters Lebensm 57:604-613

Gadd GM (2004) Mycotransformation of organic and inorganic substrates. Mycologist 18:60-70

Gadd GM (2007) Geomycology: biogeochemical transformations of rocks, minerals, metals and radionuclides by fungi, bioweathering and bioremediation. Mycol Res 111:3-49

Gadd GM (2008) Fungi and their role in the biosphere. In: Jorgensen SE, Fath B (eds) Encyclopedia of ecology. Elsevier, Amsterdam, pp 1709-1717

Gadd GM, Fomina M (2011) Uranium and fungi. Geomicrobiol J 28:471-482

Gadd GM, Rhee YJ, Stephenson K, Wei Z (2012) Geomycology: metals, actinides and biominerals. Environ Microbiol Rep 4:270-296

García MÁ, Alonso J, Melgar MJ (2009) Lead in edible mushrooms. Levels and bioconcentration factors. J Hazard Mater 167:777-783

Garner CD, Armstrong EM, Berry RE, Beddoes RL, Collison D, Cooney JA, Nigar Ertok G, Helliwell M (2000) Investigations of Amavadin. J Inorg Biochem 80:17-20

Gast CH, Jansen E, Bierling J, Haanstra L (1988) Heavy metals in mushrooms and their relationship with soil characteristics. Chemosphere 17:789-799

Gentili A, Gremigni G, Sabbatini V (1991) ${ }^{110 \mathrm{~m}} \mathrm{Ag}$ in fungi in central Italy after the Chernobyl accident. J Environ Radioact 13:75-78

Giannaccini G, Betti L, Palego L, Mascia G, Schmid L, Lanza M, Mela A, Fabbrini L, Biondi L, Lucacchini A (2012) The trace element content of top-soil and wild edible mushroom samples collected in Tuscany, Italy. Environ Monit Assess 184:7679-7585

Gryndler M, Hršelová H, Soukupová L, Borovička J (2012) Silver release from decomposed hyperaccumulating Amanita solitaria fruit-body biomass strongly affects soil microbial community. Biometals 25:987-993

Gucia M, Jarzyńska G, Kojta AK, Falandysz J (2012a) Temporal variability in twenty chemical elements content of Parasol Mushroom (Macrolepiota procera) collected from two sites over a few years. J Environ Sci Health B 47:81-88

Gucia M, Kojta AK, Jarzyńska G, Rafał E, Roszak M, Osiej I, Falandysz J (2012b) Multivariate analysis of mineral constituents of edible Parasol Mushroom (Macrolepiota procera) and soils beneath fruiting bodies collected from Northern Poland. Environ Sci Pollut Res 19:416-431

Guillén JF, Baeza A, Ontalba MA, Míguez MP (2009) ${ }^{210} \mathrm{~Pb}$ and stable lead content in fungi: its transfer from soil. Sci Total Environ 407:4320-4326

Györfi J, Geösel A, Vetter J (2010) Mineral composition of different strains of edible medicinal mushroom Agaricus subrufescens Peck. J Med Food 13:1510-1514

Hawksworth DL (2009) Mycology: a neglected megascience. In: Rai M, Bridge PD (eds) Applied mycology. CABI, Wallingford, pp 1-16 
Hobbie EA, Agerer R (2010) Nitrogen isotopes in ectomycorrhizal sporocarps correspond to belowground exploration types. Plant Soil 327:71-83

Hong J, Bañuelos GS, Fowler T, Lin Z-Q (2011) Use of seleniumladen plant materials from phytoremediation to produce seleniumbiofortified edible mushrooms. ICOBTE 2011, 11th International Conference on the Biogeochemistry of Trace Elements. Conference Proceedings Parte I, Congress Center, Florence, Italy, July 3-7, pp. 349-350

Horyna J, Řanda Z (1988) Uptake of radiocesium and alkali metals by mushrooms. J Radioanal Nucl Chem 172:107120. doi:10.1007/ BF02164600

Jarzyńska G, Falandysz J (2011a) Selenium and 17 other largely essential and toxic metals in muscle and organ meats of Red Deer (Cervus elaphus) - consequences to human health. Environ Int 37:882-888

Jarzyńska G, Falandysz J (2011b) The determination of mercury in mushrooms by CV-AAS and ICP-AES techniques. J Environ Sci Health A 46:569-573

Jarzyńska G, Falandysz J (2012a) Metallic elements profile of Hazel (Hard) Bolete (Leccinum griseum) mushroom and associated upper soil horizon. African J Biotechnol 11:45884594

Jarzyńska G, Falandysz J (2012b) Metallic elements profile of Slate Bolete (Leccinum duriusculum) mushroom and associated soil horizon. J Geochem Explor 121:69-75

Jarzyńska G, Gucia M, Kojta AK, Rezulak K, Falandysz J (2011) Profile of trace elements in Parasol Mushroom (Macrolepiota procera) from Tucholskie Forests. J Environ Sci Health B 46:741-751

Jarzyńska G, Kojta AK, Drewnowska M, Falandysz J (2012a) Notes on selenium in mushrooms data determined by inductively coupled plasma atomic emission spectroscopy (ICP-AES) and hydride generation atomic absorption spectroscopy (HG-AAS) techniques. Afr J Agric Res 7:5233-5237

Jarzyńska G, Chojnacka A, Dryżałowska A, Nnorom IC, Falandysz J (2012b) Concentrations and bioconcentration factors of minerals by Yellow-cracking Bolete (Xerocomus subtomentosus) mushroom collected in Noteć Forest, Poland. J Food Sci 77:H202H206

Jentschke G, Brandes B, Kuhn AJ, Schröder WH, Becker JS, Godbold DL (2000) The mycorrhizal fungus Paxillus involutus transports magnesium to Norway spruce seedlings. Evidence from stable isotope labeling. Plant Soil 220:243-246

Kabata-Pendias A (2011) Trace elements in soils and plants, 4th edn. CRC, Boca Raton

Kalač P, Burda J, Stašková I (1991) Concentration of lead, cadmium, mercury and copper in mushrooms in the vicinity of a lead smelter. Sci Total Environ 105:109-119

Kirchner G, Daillant O (1998) Accumulation of 210Pb, 226Ra and radioactive cesium by fungi. Sci Total Environ 222: 63-70

Klán J, Řanda Z, Benada J, Horyna J (1988) Investigation of nonradioactive $\mathrm{Rb}, \mathrm{Cs}$, and radiocaesium in higher fungi. Czech Mycol 42:158-169

Koch I, Wang L, Reimer KJ, Cullen WR (2000) Arsenic species in terrestrial fungi and lichens from Yellowknife, NWT, Canada. Appl Organomet Chem 14:245-252

Kojta AK, Gucia M, Jarzyńska G, Lewandowska M, Zakrzewska A, Falandysz J, Zhang D (2011) Phosphorous and metallic elements in Parasol Mushroom (Macrolepiota procera) and soil from the Augustowska Forest and Ełk regions in north-eastern Poland. Fresenius Environ Bull 20:3044-3052

Kojta AK, Jarzyńska G, Falandysz J (2012) Mineral composition and heavy metals accumulation capacity of Bay Bolete's (Xerocomus badius) fruiting bodies collected near a former gold and copper mining area. J Geochem Explor 121:76-82
Komárek M, Chrastný V, Štíchová J (2007) Metal/metalloid contamination and isotopic composition of lead in edible mushrooms and forest soils originating from a smelting area. Environ Int 33:677-684

Kostiainen E (2007) ${ }^{137} \mathrm{Cs}$ in Finnish wild berries, mushrooms and game meat in 2000-2005. Boreal Environ Res 12:23-28

Landeweert R, Hoffland E, Finlay RD, Kuyper TW, van Breemen N (2001) Linking plants to rocks: ectomycorrhizal fungi mobilize nutrients from minerals. Trends Ecol Evol 16:248-254

Larsen EH, Hansen M, Gössler W (1998) Speciation and health risk considerations of arsenic in the edible mushroom Laccaria amethystina collected from contaminated and uncontaminated locations. Appl Organomet Chem 12:285-291

Lavola A, Aphalo PJ, Lehto T (2011) Boron and other elements in sporophores of ectomycorrhizal and saprotrophic fungi. Mycorrhiza 21:155-165

Lepp NW, Harrison SCS, Morrell BG (1987) A role for Amanita muscaria $\mathrm{L}$. in the circulation of cadmium and vanadium in non-polluted woodland. Environ Geochem Health 9:61-64

Li T, Wang YZ, Zhang J, Zhao YL, Liu H (2011) Trace element content of Boletus tomentipes mushroom collected from Yunnan, China. Food Chem 127:1828-1830

Liu H, Zhang J, Li T, Shi Y, Wang Y (2012) Mineral element levels in wild edible mushrooms from Yunnan, China. Biol Trace Elem Res 147:341-345

Luis P, Kellner H, Zimdars B, Langer U, Martin F, Buscot F (2005) Patchiness and spatial distribution of laccase genes of ectomycorrhizal, saprotrophic, and unknown basidiomycetes in the upper horizons of a mixed forest cambisol. Microb Ecol 50:570-579

Machat J, Otruba V, Kanicky V (2002) Spectral and non-spectral interferences in the determination of selenium by inductively coupled plasma atomic emission spectrometry. J Anal At Spectrom 17:1096-1102

Maćkiewicz D, Falandysz J (2012) Total mercury in Yellow Kinights (Tricholoma equestre) mushrooms and beneath soils. Bull Environ Contam Toxicol 89:755-758

Maihara VA, Moura PL, Catharino MG, Castro LP, Figueira RCL (2008) Arsenic and cadmium content in edible mushrooms from São Paulo, Brazil determined by INAA and GF AAS. J Radioanal Nucl Chem 278:395-397

Malinowska E, Szefer P, Falandysz J (2004) Metals bioaccumulation by bay bolete Xerocomus badius from selected sites in Poland. Food Chem 84:405-416

Manzi P, Gambelli L, Marconi S, Vivanti V, Pizzoferrato L (1999) Nutrients in edible mushrooms: an inter-species comparative study. Food Chem 65:477-482

Melgar MJ, Alonso J, Garcia MÁ (2009) Mercury in edible mushrooms and soil. Bioconcentration factors and toxicological risk. Sci Total Environ 407:5328-5334

Mietelski JW, Baeza AS, Guillen J, Buzinny M, Tsigankov N, Gaca P, Jasińska M, Tomankiewicz E (2002) Plutonium and other alpha emitters in fruitbodies from Poland, Spain and Ukraine. Appl Radiat Isot 56:717-729

Mietelski JW, Dubchak S, Błażej S, Anielska T, Turnau K (2010) ${ }^{137} \mathrm{Cs}$ and ${ }^{40} \mathrm{~K}$ in fruiting bodies of different fungal species collected in a single forest in southern Poland. J Environ Radioact 101:706-711

Muñoz AHS, Corona FG, Wrobel K, Soto GM, Wrobel K (2005) Subcellular distribution of aluminum, bismuth, cadmium, chromium, copper, iron, manganese, nickel, and lead in cultivated mushrooms (Agaricus bisporus and Pleurotus ostreatus). Biol Trace Elem Res 106:265-277

Nasr M, Arp PA (2011) Hg concentrations and accumulations in fungal fruiting bodies, as influenced by forest soil substrates and moss carpets. Applied Geochemistry 26:1905-1917

Nnorom IC, Jarzyńska G, Falandysz J, Drewnowska M, Okoye I, OjiNnorom Ch G (2012a) Occurrence and accumulation of mercury 
in two species of wild grown Pleurotus mushrooms from Southeastern Nigeria. Ecotoxicol Environ Saf 84:78-83

Nnorom IC, Jarzyńska G, Falandysz J, Drewnowska M, Pankavec S, Kojta AK (2012b) Analysis of twenty major and trace elements in sclerotium of Pleurotus tuber-regium (Ósū) mushroom from Southeastern Nigeria. J Food Compos Anal. doi:10.1016/ j.jfca.2012.10.00.1

Osobová M, Urban V, Jedelský PL, Borovička J, Gryndler M, Ruml T, Kotrba P (2011) Three metallothionein isoforms and sequestration of intracellular silver in the hyperaccumulator Amanita strobiliformis. New Phytol 90:916-926

Petrini O, Cocchi L, Vescovi L, Petrini L (2009) Chemical elements in mushrooms: their potential taxonomic significance. Mycol Prog 8:171-180

Pilz C, Santos CMM, Nunes NAC, Müller EI, Flores ÉMM, Dressler VL (2011) Speciation of $\mathrm{Hg}$ in edible mushroom. International Symposium Trace Elements in Food (TEF-4) King's College, Aberdeen, Scotland, 19-22 June 2011. P/65/0107

Plassard C, Louche J, Ali MA, Duchemin M, Legname E, CloutierHurteau B (2011) Diversity in phosphorus mobilisation and uptake in ectomycorrhizal fungi. Ann For Sci 68:33-43

Quiquampoix H, Burns RG (2008) Interactions between proteins and soil mineral surfaces: environmental and health consequences. Elements 3:369-440

Ramesh G, Podila GK, Gay G, Marmeisse R, Reddy MS (2009) Different patterns of regulation for copper and cadmium metallothioneins of the ectomycorrhizal fungus Hebeloma cylindrosporum. Appl Environ Microbiol 75:2266-2274

Řanda Z, Kučera J (2004) Trace elements in higher fungi (mushrooms) determined by activation analysis. J Radioanal Nucl Chem 259:99-107

Rayman MP (2008) Food-chain selenium and human health: emphasis on intake. Br J Nutr 100:254-268

Reider SR, Brunner I, Horvat M, Jacobs A, Frey B (2011) Accumulation of mercury and methylmercury by mushrooms and earthworms from forest soils. Environ Pollut 159:2861-2869

Reisinger A (1994) Radiocaesium in macrofungi [In German]. Bibl Mycol 155:1-174

Rhee YJ, Hillier S, Gadd GM (2012) Lead transformation to pyromorphite by fungi. Curr Biol 22:237-241

Rosén K, Vinichuk M, Nikolova I, Johanson K (2011) Long-term effects of single potassium fertilization on 137Cs levels in plants and fungi in a boreal forest ecosystem. J Environ Radioact 102:178-184

Rudawska M, Leski T (2005a) Macro- and microelement contents in fruiting bodies of wild mushrooms from the Notecka forest in west-central Poland. Food Chem 92:499-506

Rudawska M, Leski T (2005b) Trace elements in fruiting bodies of ectomycorrhizal fungi growing in Scots pine (Pinus sylvestris L.) stands in Poland. Sci Total Environ 339:103-115

Rühm W, Kammerer L, Hiersche L, Wirth E (1997) The ${ }^{137} \mathrm{Cs} /{ }^{134} \mathrm{Cs}$ ratio in fungi as indicator of the major mycelium location in forest soil. J Environ Radioact 35:129-148

Senn-Irlet B, Heilmann-Clausen J, Genney D, Dahlberg A (2007) Gudiance for conservation of macrofungi in Europe. Document prepared for the European Council for Conservation of Fungi (ECCF) within the European Mycological Association (EMA) and the Directorate of Culture and Cultural and Natural Heritage, Council of Europe, Strasbourg

Silva MCS, Naozuka J, Oliveira PV, Vanetti MCD, Bazzolli DMS, Costa NMB, Kasuya MCM (2010) In vivo bioavailability of selenium in enriched Pleurotus ostreatus mushrooms. Metallomics 2:162-166

Skwarzec B (2012) Radioactivity. In: Jorgensen SE (ed) Encyclopedia of environmental management. Taylor \& Francis, New York. doi:10.1081/E-EEM-120046097
Skwarzec B, Jakusik A (2003) ${ }^{210}$ Po bioaccumulation by mushrooms from Poland. J Environ Monit 5:791-794

Šlejkovec Z, Byrne AR, Stijve T, Goessler W, Irgolic KJ (1997) Arsenic compounds in higher fungi. Appl Organomet Chem 11:673-682

Šlejkovec Z, Elteren JT, Woroniecka UD, Kroon KJ, Falnoga I, Byrne AR (2000) Preliminary study on the determination of selenium compounds in some selenium-accumulating mushrooms. Biol Trace Elem Res 75:139-155

Smith ML, Bruhn JN, Anderson JB (1992) The fungus Armillaria bulbosa is among the largest and oldest living organisms. Nature 356:428-431

Smits MM, Hoffland E (2009) Possible role of ectomycorrhizal fungi in cycling of aluminium in podzols. Soil Biol Biochem 41:491-497

Soeroes Cs, Kienzl N, Ipolyi I, Dernovics M, Fodor P, Kuehnelt D (2005) Arsenic uptake and arsenic compounds in cultivated Agaricus bisporus. Food Control 16:459-464

Stijve T, Besson R (1976) Mercury, cadmium, lead, and selenium content of mushroom species belonging to the genus Agaricus. Chemosphere 5:151-158

Stijve T, de Meijer AAR (1999) Hydrocyanic acid in mushrooms, with special reference to wild-growing and cultivated edible species. Dtsch Lebensm Rundsch 95:366-373

Stijve T, Vellinga EC, Herrmann A (1990) Arsenic accumulation in some higher fungi. Persoonia 14:161-166

Stijve T, Noorloos T, Byrne AR, Šlejkovec Z, Goessler W (1998) High selenium levels in edible Albatrellus mushroom. Dtsch Lebensm Rundsch 94:275-279

Stijve T, Andrey D, Goessler W, Guinberteau J, Dupuy G (2001) Comparative study of heavy metals and other trace elements in Gyrophragmium dunalii and in yellowish Agaricus of the subsection Arvenses [In French]. Bull Trimest Soc Mycol Fr 117:133144

Strandberg M (2004) Long-term trends in the uptake of radiocesium in Rozites caperatus. Sci Total Environ 327:315-321

Sun L, Liu G, Yang M, Zhuang Y (2012) Bioaccessibility of cadmium in fresh and cooked Agaricus blazei Murill assessed by in vitro biomimetic digestion system. Food Chem Toxicol 50:1729-1733

Svoboda L, Zimmermannová K, Kalač P (2000) Concentrations of mercury, cadmium, lead and copper in fruiting bodies of edible mushrooms in an emission area of a copper smelter and a mercury smelter. Sci Total Environ 246:61-67

Svoboda L, Kalač P, Špička J, Janoušková D (2002) Leaching of cadmium, lead and mercury from fresh and differently preserved edible mushrooms, Xerocomus badius, during soaking and boiling. Food Chem 79:41-45

Szántó Z, Hult M, Wätjen U, Altzitzoglou T (2007) Current radioactivity content of wild edible mushrooms: a candidate for an environmental reference material. J Radioanal Nucl Chem 273:167-170

Szubstarska J, Jarzyńska G, Falandysz J (2012) Trace elements of Variegated Boletes (Suillus variegatus) mushrooms. Chem Pap 66:1026-1032

Taira Y, Hayashidai N, Brahmanandhan GM, Nagayama Y, Yamashita S, Takahashi J, Gutenitc A, Kazlovsky A, Urazalin M, Takamura N (2011) Current concentration of artificial radionuclides and estimated radiation doses from $137 \mathrm{Cs}$ around the Chernobyl nuclear power plant, the Semipalatinsk nuclear testing site, and in Nagasaki. J Radiat Res 52:88-95

Tsvetnova OB, Shcheglov AI (1994) ${ }^{137} \mathrm{Cs}$ content in the mushrooms of radioactive contaminated zones of the European part of the CIS. Sci Total Environ155:25-29

Turło J, Gutkowska B, Herold F, Dawidowski M, Słowiński T, Zobel A (2010) Relationship between selenium accumulation and mycelial cell composition in Lentinula edodes (Berk.) cultures. J Toxicol Environ Health A 73:1211-1219 
Tüzen M, Soylak M (2005) Mercury contamination in mushroom samples from Tokat, Turkey. Bull Environ Contam Toxicol 74:968-972

Tüzen M, Sesli E, Soylak M (2007) Trace element levels of mushroom species from East Black Sea region of Turkey. Food Control $18: 806-810$

Urban A (2011) Chapter 11. Metal elements and the diversity and function of ectomycorrhizal communities. In: Rai M, Varma A (eds) Diversity and biotechnology of ectomycorrhizae. Soil Biology, vol 25. Springer, Berlin, pp 231-254

Vaartamaa K, Solatie D, Aro L (2009) Distribution of ${ }^{210} \mathrm{~Pb}$ and boreal forest ecosystems ${ }^{210} \mathrm{Po}$ concentrations in wild berries and mushrooms. Sci Total Environ 408:84-91

van Schöll L, Hoffland E, van Breemen N (2006a) Organic anion exudation by ectomycorrhizal fungi and Pinus sylvestris in response to nutrient deficiencies. New Phytol 170:153-163

van Schöll L, Smits MM, Hoffland E (2006b) Ectomycorrhizal weathering of the soil minerals muscovite and hornblende. New Phytol 171:805-814

Vetter J (2003) Chemical composition of fresh and conserved Agaricus bisporus mushroom. Eur Food Res Technol 217:10-12

Vetter J (2005) Lithium content of some common edible wild-growing mushrooms. Food Chem 90:31-37

Vetter J, Hajdú J, Györfi J, Maszlavér P (2005) Mineral composition of the cultivated mushrooms Agaricus bisporus, Pleurotus ostreatus and Lentinula eodes. Acta Alim 34:441-451

Vinichuk M, Rosén K, Johanson KJ, Dahlberg A (2011) Cesium $\left({ }^{137} \mathrm{Cs}\right.$ and ${ }^{133} \mathrm{Cs}$ ), potassium and rubidium in macromycete fungi and sphagnum plants. In: Singh N (ed) Radioisotopes-applications in physical sciences. InTech, Rijeka. doi:10.5772/22263, 496 pages. ISBN 978-953-307-510-5
Wallander H (2000a) Uptake of P from apatite by Pinus sylvestris seedlings colonized by different ectomycorrhizal fungi. Plant Soil 218:249-256

Wallander H (2000b) Use of strontium isotopes and foliar K content to estimate weathering of biotite induced by pine seedlings colonised by ectomycorrhizal fungi from two different soils. Plant Soil 222:215-229

Wallander H, Wickman T (1999) Biotite and microcline as potassium sources in ectomycorrhizal and non-mycorrhizal Pinus sylvestris seedlings. Mycorrhiza 9:25-32

Wondratschek I, Röder U (1993) Monitoring of heavy metals in soils by higher fungi. In: Markert B (ed) Plants as biomonitors, indicators for heavy metals in the terrestrial environment. $\mathrm{VCH}$, Weinheim, pp 345-363

Yin L-L, Shi G-Q, Tian Q, Shen T, Ji Y-Q, Zeng G (2012) Determination of the metals by ICP-MS in wild mushrooms from Yunnan, China. J Food Sci 77:151-155

Zellner J (1907) Chemistry of macrofungi [In German]. Verlag von Wilhelm Engelmann, Leipzig

Zhang D, Frankowska A, Jarzyńska G, Kojta AK, Drewnowska M, Wydmańska D, Bielawski L, Wang J, Falandysz J (2010) Metals of King Bolete (Boletus edulis) collected at the same site over two years. Afr J Agric Res 5:3050-3055

Zhang D, Bielawski L, Jarzyńska G, Morawska E, Drewnowska G, Falandysz J (2013) Trace elements in Leccinum scabrum mushrooms and soils from Kłodzka Dale in Sudety Mountains, Poland. J Mt Sci 10 (accepted)

Zhao L, Zhao G, Zhao Z, Chen P, Tong J, Hu X (2004) Selenium distribution in a Se-enriched mushroom species of the genus Ganoderma. J Agric Food Chem 52:3954-3959 